\title{
The world fauna of Synchroidae Lacordaire, 1859 (Coleoptera, Tenebrionoidea, Synchroidae)
}

\author{
Yun HSIAO ${ }^{1}$, Ondřej KONVIČKA ${ }^{2}$ \& Chiun-Cheng KO ${ }^{3, *}$ \\ ${ }^{1,3}$ Department of Entomology, National Taiwan University, No. 27, Lane 113, \\ Sec. 4, Roosevelt Rd., Taipei 10617, Taiwan. \\ ${ }^{2}$ Institute of Entomology, Biology Centre CAS, Branišovská 31, \\ 37005 České Budějovice, Czech Republic. \\ ${ }^{2}$ Kúty 1959, 76001 Zlín, Czech Republic. \\ ${ }^{*}$ Corresponding author: kocc2501@ntu.edu.tw \\ ${ }^{1}$ Email: yunhsiao@outlook.com \\ ${ }^{2}$ Email: brouk.vsetin@centrum.cz \\ ${ }^{1}$ urn:1sid:zoobank.org:author:6E5C734A-1809-46A1-A595-5A0CB7B39BA0
${ }^{2}$ urn:Isid:zoobank.org:author:F0165D8E-85B8-44BF-AA8E-82F50DA22C8A
${ }^{3}$ urn:1sid:zoobank.org:author:1999FEB9-385C-453C-A7C4-B5C24552392E
}

\begin{abstract}
Synchroidae Lacordaire, 1859 is a taxonomically and biologically poorly known group. In the present paper, diagnostic characters used to separate genera are analysed and the phylogenetic relationships within this family are preliminarily investigated. Results suggest that the characteristic Synchroa pangu Hsiao, Li, Liu \& Pang, 2016 can be removed to establish a new genus, Thescelosynchroa gen. nov. The new combination, T. pangu (Hsiao, Li, Liu \& Pang) gen. et comb. nov., is proposed. The definitions of Synchroa Newman, 1838 and Synchroina Fairmaire, 1898 are revised. Moreover, morphological analysis and character comparison also suggest that the familial placement of Mallodrya subaenea Horn, 1888 is questionable. Six species are re-examined and rediagnosed: Synchroa chinensis Nikitsky, 1999, S. elongatula Nikitsky, 1999, S. formosana Hsiao, 2015, S. melanotoides Lewis, 1895, S. punctata Newman, 1838 and Synchroina tenuipennis Fairmaire, 1898. The male of $S$. chinensis and the female of $S$. formosana are described for the first time. Synchroa elongatula and Synchroina tenuipennis are newly recorded from Laos and Indonesia, respectively. We also hypothesize that the Eastern Asian-North American disjunction of Synchroa could be connected to a Mid-Late Tertiary migration of plants via the Bering Land Bridge.
\end{abstract}

Keywords. Synchroa bark beetles, taxonomy, phylogeny, new genus, EA-ENA disjunction.

Hsiao Y., Konvička O. \& Ko C.-C. 2018. The world fauna of Synchroidae Lacordaire, 1859 (Coleoptera, Tenebrionoidea, Synchroidae). European Journal of Taxonomy 407: 1-33. https://doi.org/10.5852/ejt.2018.407

\section{Introduction}

Synchroidae Lacordaire, 1859 is a small family, including only nine extant species subdivided amongst three genera (Nikitsky 1999; Hsiao 2015; Hsiao et al. 2016); the fossil record includes only one species 
from the Eocene Florissant Formation of Colorado (Wickham 1911). Comparative morphological studies of larval characters suggest that synchroids may be more closely related to Zopheridae and Stenotrachelidae than Melandryidae, although adult synchroids and melandryids are extremely similar in overall appearance (Böving \& Craighead 1931; Crowson 1966). Synchroidae was recovered as sister to a clade including Pterogeniidae, Tetratomidae, Mycetophagidae, Archeocrypticidae, Chalcodryidae, Promecheilidae and Ulodidae (McKenna et al. 2015) although the results are not exhaustive due to the low number of species included in the analyses.

Synchroids are generally poorly known and notoriously difficult to collect, except Synchroa punctata Newman, 1838 and S. melanotoides Lewis, 1895. Furthermore, the majority of the species were described based on a single or few specimens, including females, and diagnostic characters and intraspecific variation have been scarcely considered. During our study more specimens of previously described species were examined. This paper aims to provide precise information on the morphology of Synchroidae, with major emphasis on the diagnostic characters. Synchroa chinensis Nikitsky, 1999, S. melanotoides Lewis, 1895, S. punctata Newman, 1838 and Synchroina tenuipennis Fairmaire, 1898 are redescribed, and the male of S. chinensis and female of S. formosana Hsiao, 2015 are described for the first time. Synchroa elongatula Nikitsky, 1999 and Synchroina tenuipennis are newly reported from Laos and Indonesia, respectively. The previously established key for the identification of Synchroidae (Nikitsky 1999; Hsiao 2015; Hsiao et al. 2016) is modified. In addition, a morphologybased phylogenetic analysis including all described taxa of Synchroidae is performed. The results reveal that Synchroa pangu Hsiao, Li, Liu \& Pang, 2016 cannot be assigned to any previously described genus. Together with the morphological comparison, we herein separate this species to establish a new genus, Thescelosynchroa gen. nov., with a new combination proposed: T. pangu (Hsiao, Li, Liu \& Pang, 2016) gen. et comb. nov. Furthermore, a preliminary and brief discussion of familial placement of Mallodrya subaenea Horn, 1888 and the biogeography of the family are provided.

\section{Material and methods}

All specimens examined in this paper are deposited in the following institutions and private collections:

HUM = Hokkaido University Museum, Sapporo, Japan

MAIC = Michael A. Ivie collection, Montana State University, Bozeman, USA

NMNS = National Museum of Natural Science, Taichung, Taiwan

OKZC $=$ O. Konvička's private collection, Zlín, Czech Republic

SYSBM = Museum of Biology, Sun Yat-Sen University, Guangzhou, China (mainland)

TARI = Taiwan Agricultural Research Institute, Wufeng, Taichung, Taiwan

TFRI = Taiwan Forestry Research Institute, Taipei, Taiwan

YHC $=$ Y. Hsiao's private collection, Taichung, Taiwan

Terminology for morphology used in the paper follows Ślipiński \& Lawrence (2010) and Hsiao (2015). Abdomens detached from the body were kept in $20 \% \mathrm{KOH}$ for 1-2 hours before observation. Elytra were detached and placed in $75 \%$ alcohol to make the elytral striae clearer to examine. Photographs and measurements were produced following Hsiao (2015) and Hsiao et al. (2016). The distribution map was prepared using the SimpleMappr program (Shorthouse 2010).

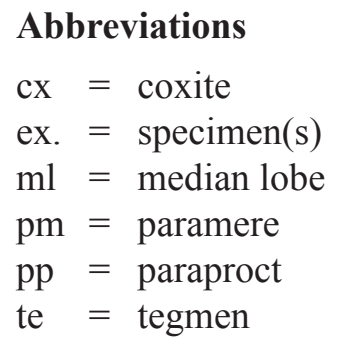




\section{Characters}

Twenty eight adult morphological characters and one geographical character were used for the phylogenetic analysis, listed as follows:

01 Body size: (0) small (6.5-9.0 mm); (1) large (> $10.0 \mathrm{~mm})$.

02 Body form judged on the ratio of the length to the width at the widest part of the conjoint elytra: (0) distinctly widened posteriorly (ca 2.85); (1) strongly narrowed posteriorly, flattened (ca 3.40$3.60)$; (2) lateral sides of elytra parallel in anterior half, similar to (1), but more slender (ca 3.804.00); (3) considerably slender (> 5.0).

03 Shape of head: (0) stout (Fig. 1A); (1) elongate, abruptly constricted posteriorly to form broad neck (Fig. 1B).

04 Frontoclypeus: (0) broad (Fig. 1A); (1) narrow (Fig. 1B).

05 Mandible: (0) stout, obtuse (Fig. 1C); (1) slender, acute (Fig. 1D).

06 Shape of eyes in dorsal view: (0) oval, shallowly emarginate (Fig. 1A); (1) deeply emarginate (Fig. 1B).

07 Eyes size judged on the ratio of eye diameter to interocular space in males: (0) large, eye diameter longer than interocular space; (1) middle, ca 1.5-1.7; (2) smaller than (1), ca 1.8-2.2; (3) very small, ca 3.0.

08 Interfacetal setae: (0) very short or absent; (1) usually with long interfacetal setae.

09 Shape of apical maxillary palpomere: (0) stout, subtriangular (Fig. 1E); (1) stout, more elongate than (0), obliquely truncate (Fig. 1F); (2) securiform (Fig. 1G); (3) elongate and more expanded (Fig. 1H).

10 Form of antennae: (0) filiform (Fig. 1I); (1) filiform, with last three segments expanded (Fig. 1J); (2) submonoliform, antennomeres IV-X gradually shortened; antennomere XI oval (Fig. 1K).

11 Shape of pronotum: (0) transverse, lateral sides strongly narrowed anteriorly, with complete lateral carinae (Fig. 2A); (1) transverse, lateral sides feebly arcuate, with complete lateral carinae (Fig. 2B); (2) transverse, lateral sides somewhat rounded, moderately narrowed anteriorly, with complete lateral carinae (Fig. 2C); (3) bell-shaped, with incomplete lateral carinae (Fig. 2D).

12 Posterior edge of pronotum: (0) unmargined; (1) margined.

13 Lateral pronotal carinae: (0) lateral sides unmargined; (1) lateral sides entirely or partially margined.

14 Greatest width of pronotum: (0) distinctly narrower than elytra ( $\leq 0.8$ times elytral width at humeri); (1) as wide as elytra at humeri.

15 Prosternum in front of coxae: (0) shorter than shortest diameter of procoxal cavity; (1) as long as or longer than shortest diameter of procoxal cavity.

16 Prosternal process: (0) complete, broad, extending well beyond procoxae, the apex narrowed apically (Fig. 2E); (1) complete, broad, extending well beyond procoxae, the apex long oval (Fig. 2F); (2) complete, laminate, ending just before posterior edges of procoxae; (3) incomplete.

17 Surface of mesoventral cavity: (0) absent; (1) present, the surface distinctly punctate (Fig. 2G); (2) present, the surface smooth (Fig. 2H).

18 Median field of metathoracic wings: (0) with entire subcubital fleck; (1) without subcubital fleck.

19 Procoxae: (0) not projecting below prosternum; (1) slightly projecting below prosternum; (2) projecting well below prosternum. 
20 Meso-metaventral junction: (0) absent; (1) with a complex fitting.

21 Epipleuron: (0) incomplete; (1) complete.

22 Apical edge of sternite IX in male: (0) without spiculum gastrale; (1) with short spiculum gastrale.

23 Tergite IX and X: (0) completely fused; (1) tergite IX in males emarginate, tergite X well developed and free.

24 Pretarsal claws: (0) simple; (1) serrate.

25 Pretarsal lobe: (0) with ventral lobe beneath each claw; (1) without ventral lobe.

26 Parameres: (0) separated; (1) fused together forming apicale (Fig. 2J).

27 Median lobe of aedeagus (Fig. 2J): (0) short, stout, tube-like; (1) elongate, slender, tapered; (2) elongate, slender, clavate.

28 Ovipositor (Fig. 2K): (0) with styli; (1) without styli.

29 Zoogeographical regions: (0) Palearctic region; (1) Oriental region; (2) Nearctic region.

The ingroup taxa include all described species of Synchroidae. The outgroup taxon is Cephaloon pallens (Motschulsky, 1860), Stenotrachelidae Thomson, 1859, which was considered to be related to synchroids based on immature morphology (Böving \& Craighead 1931; Crowson 1966; Hayashi 1975). The data matrix (Table 1) was coded and edited with WinClada ver. 10.00.08 (Nixon 2002). Inapplicable data were coded as '-' and missing data were coded with '?'. Characters were coded based on our own anatomical observations and descriptions provided by Horn (1888), Nikitsky (1999) and Ślipiński \& Lawrence (2010). The data matrix was analysed using NONA v. 2.0 (Goloboff 1999) from WinClada. All characters were run equally weighted and not additive. The commands of heuristic analysis, 'hold 10000', 'mult*50', 'hold/20' and 'mult*max*' were used to search for the most parsimonious tree(s). In the resultant trees, the unsupported nodes were hard collapsed and only the best trees were kept in WinClada. The characters and character states on the tree were optimized using unambiguous character changes in WinClada.

\section{Character analysis}

Diagnostic characters of Synchroidae and intergeneric/intraspecific variation are listed and discussed as follows:

01 Body size. Synchroa species are mostly $10.0-13.0 \mathrm{~mm}$ although a few exceptional specimens are ca 8.0-9.0 mm. The length varies from 7.0-9.0 mm in Synchroina and from 6.0-8.5 mm in Mallodrya according to the original description (Horn 1888).

02 Body form. Mallodrya is characterized by its elongate, oblong and somewhat convex body, which is widened posteriorly. It is similar to melandryid genera such as Melandrya (Melandrya) Fabricius, 1801 and M. (Emmesa) Newman, 1838 (Horn 1888). Synchroa (excl. S. elongatula Nikitsky, 1999 and S. pangu Hsiao, Li, Liu \& Pang, 2016) and Synchroina are similar in overall appearance, with the length ca 3.4-3.6 times as long as maximum width and flat body. S. elongatula and S. pangu are more slender, with the length ca 3.8-4.0 times as long as maximum width.

03 Antennae. Synchroa and Synchroina possess filiform antennae (Fig. 1I). Sexual dimorphism is notable. Male antennae are longer than in females. Mallodrya can be distinguished from remaining synchroids by its short antennae; gradually shortened antennomeres IV-X; oval antennomere XI (Horn 1888) (Fig. 1K).

04 Shape of apical maxillary palpomere. The apical maxillary palpomere of Synchroa is slightly more elongate and more sharply truncate apically (Fig. 1G) than in Synchroina (Fairmaire 1898; Nikitsky 

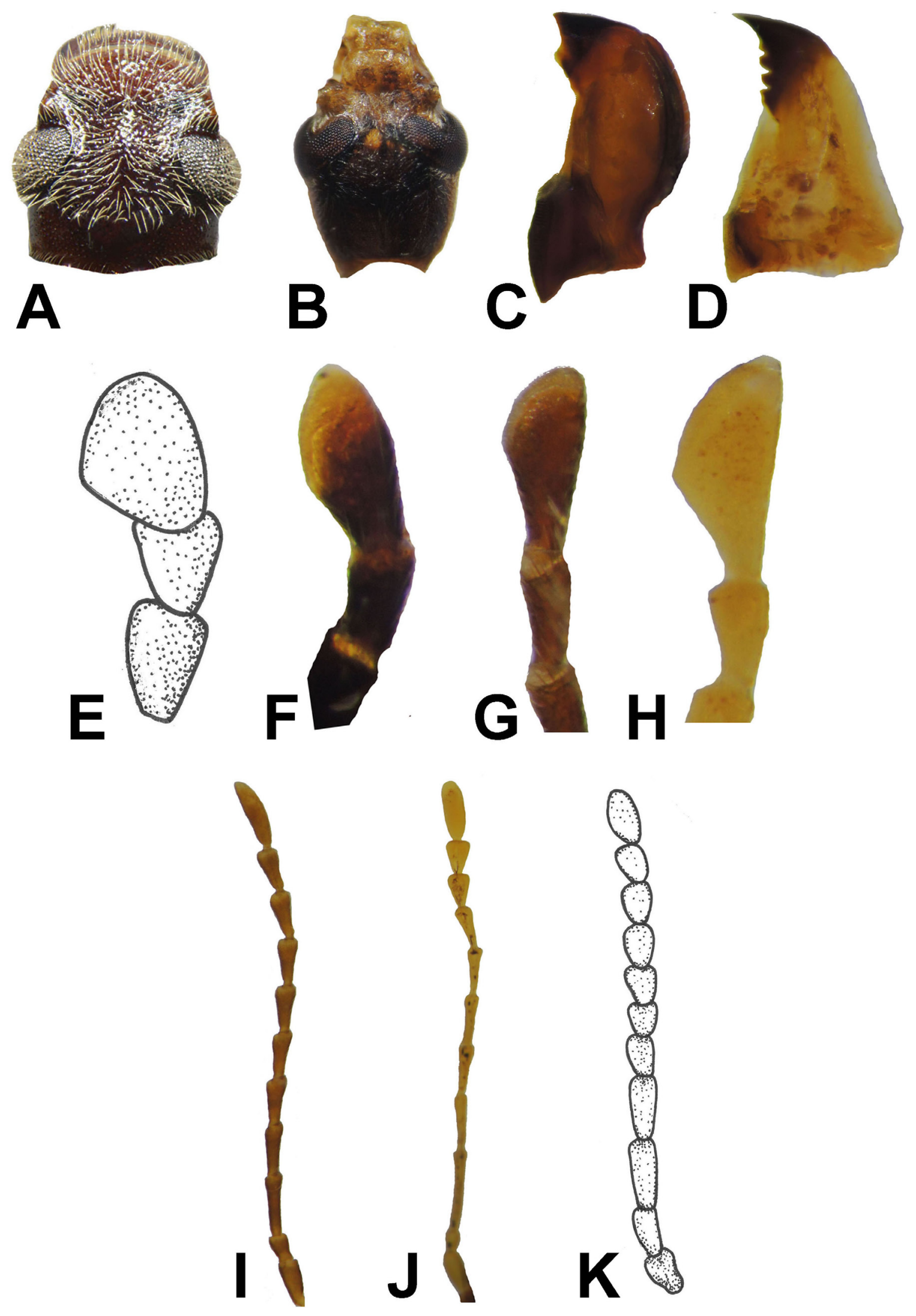

Fig. 1. Morphological characters used for the analysis. A-B. Head. C-D. Mandible. E-H. Apical maxillary palpomere. I-K. Antenna. 
1999) (Fig. 1F). In Mallodrya, the apical maxillary palpomere is stout, subtriangular and arcuate distally (Fig. 1E).

05 Eyes. Eyes are lateral, oval, and emarginate in front of antennal insertions in synchroids, with long interfacetal setae (excl. Mallodrya). The eyes are large in Synchroa (excl. S. pangu), with ratio of eye diameter to interocular space ca 1.2-1.7 and small in Synchroa pangu and species of Synchroina, with ratio of eye diameter to interocular space ca 1.8-2.2. The eyes of Mallodrya subaenea are similar to other synchroids, but very small, lacking long interfacetal setae, with a ratio of eye diameter to interocular space ca 3.0.
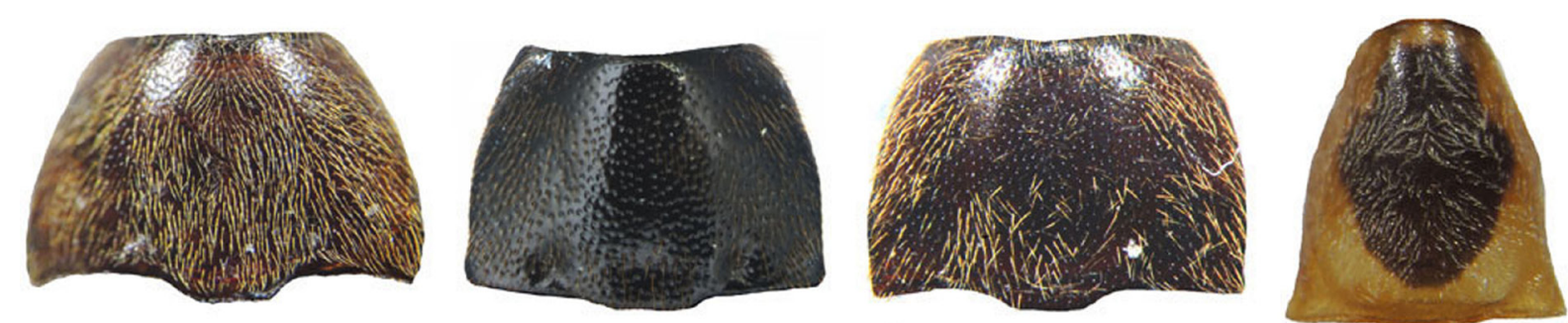

A
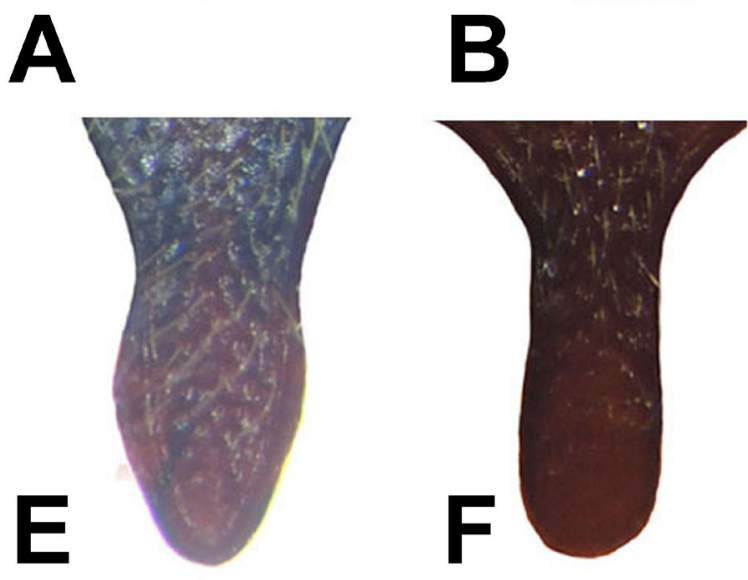

C

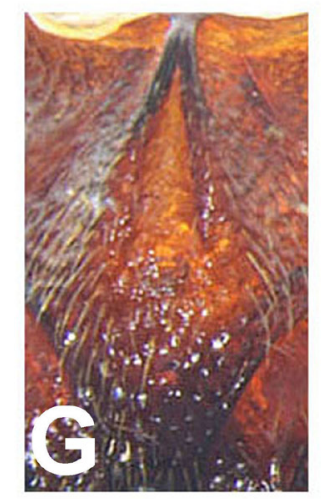

\section{D}
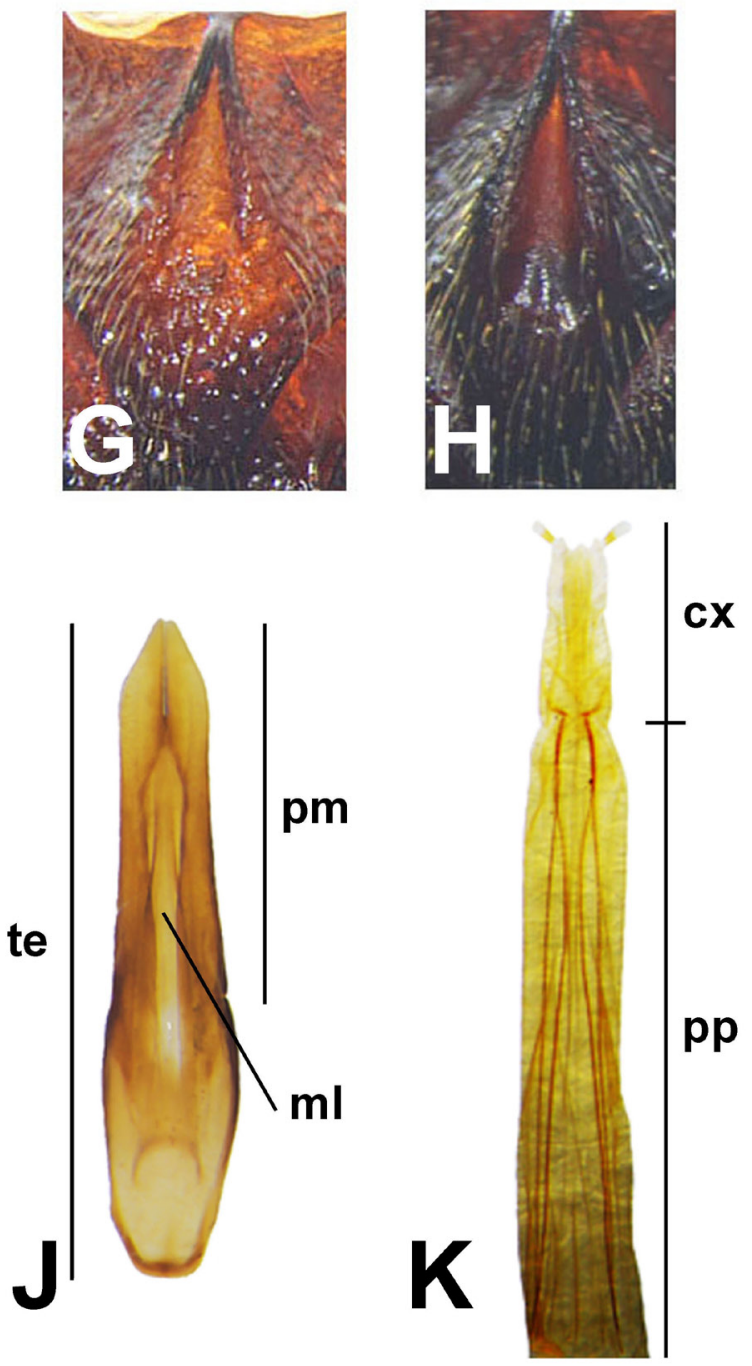

Fig. 2. Morphological characters used for the analysis and key. A-D. Pronotum. E-F. Prosternal process. G-H. Mesoventral cavity. I. Elytral striae. J. Aedeagus. K. Ovipositor. 
Table 1. Data matrix.

\begin{tabular}{|c|c|c|c|c|c|c|c|c|c|c|}
\hline 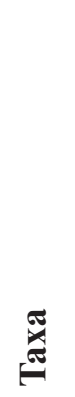 & 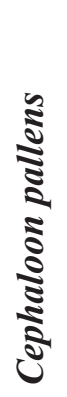 & 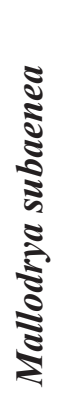 & 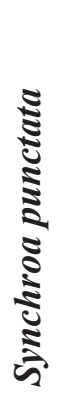 & 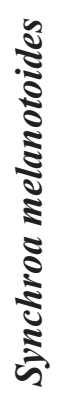 & 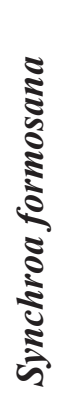 & 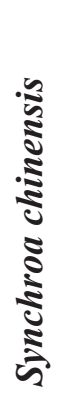 & 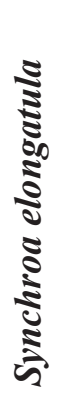 & 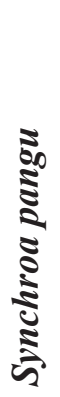 & 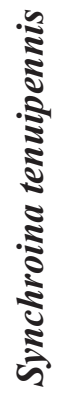 & 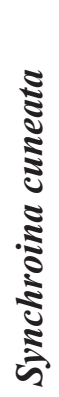 \\
\hline 01 & 1 & 0 & 1 & 1 & 1 & 1 & 1 & 1 & 0 & 0 \\
\hline 02 & 3 & 0 & 1 & 1 & 1 & 1 & 2 & 2 & 1 & 1 \\
\hline 03 & 1 & 0 & 0 & 0 & 0 & 0 & 0 & 0 & 0 & 0 \\
\hline 04 & 1 & 0 & 0 & 0 & 0 & 0 & 0 & 0 & 0 & 0 \\
\hline 05 & 1 & 0 & 0 & 0 & 0 & 0 & 0 & 0 & 0 & 0 \\
\hline 06 & 1 & 0 & 0 & 0 & 0 & 0 & 0 & 0 & 0 & 0 \\
\hline 07 & 0 & 3 & 1 & 1 & 1 & 1 & 1 & 2 & 2 & 2 \\
\hline 08 & 0 & 0 & 1 & 1 & 1 & 1 & 1 & 1 & 1 & 1 \\
\hline 09 & 3 & 0 & 2 & 2 & 2 & 2 & 2 & 2 & 1 & 1 \\
\hline 10 & 1 & 2 & 0 & 0 & 0 & 0 & 0 & 0 & 0 & 0 \\
\hline 11 & 3 & 2 & 0 & 0 & 0 & 0 & 0 & 1 & 2 & 2 \\
\hline 12 & 1 & 1 & 0 & 0 & 0 & 0 & 0 & 0 & 0 & 0 \\
\hline 13 & - & 1 & 1 & 1 & 0 & 0 & 1 & 0 & 1 & 1 \\
\hline 14 & 0 & 1 & 1 & 1 & 1 & 1 & 1 & 0 & 1 & 1 \\
\hline 15 & 0 & 1 & 1 & 1 & 1 & 1 & 1 & 1 & 1 & 1 \\
\hline 16 & 3 & 2 & 1 & 1 & 0 & 0 & 0 & 1 & 0 & 0 \\
\hline 17 & 0 & 0 & 1 & 1 & 1 & 1 & 1 & 1 & 2 & 2 \\
\hline 18 & 1 & 0 & 0 & 0 & 0 & 0 & 0 & $?$ & 0 & 0 \\
\hline 19 & 2 & 1 & 0 & 0 & 0 & 0 & 0 & 0 & 0 & 0 \\
\hline 20 & 0 & 0 & 1 & 1 & 1 & 1 & 1 & 1 & 1 & 1 \\
\hline 21 & 1 & 0 & 0 & 0 & 0 & 0 & 0 & 0 & 0 & 0 \\
\hline 22 & 1 & 0 & 0 & 0 & 0 & 0 & 0 & $?$ & 0 & 0 \\
\hline 23 & 1 & 0 & 0 & 0 & 0 & 0 & 0 & $?$ & 0 & 0 \\
\hline 24 & 1 & 0 & 0 & 0 & 0 & 0 & 0 & 0 & 1 & 1 \\
\hline 25 & 0 & 1 & 1 & 1 & 1 & 1 & 1 & 1 & 1 & 1 \\
\hline 26 & 0 & $?$ & 1 & 1 & 1 & 1 & 1 & 1 & 1 & 1 \\
\hline 27 & 0 & $?$ & 1 & 1 & 1 & 1 & 1 & 2 & 2 & 2 \\
\hline 28 & 1 & $?$ & 0 & 0 & 0 & 0 & 0 & $?$ & 0 & $?$ \\
\hline 29 & 0 & 2 & 2 & 0 & 1 & 0 & 1 & 0 & 1 & 1 \\
\hline
\end{tabular}

06 Shape of pronotum. In Synchroa (excl. S. pangu), the lateral sides of the pronotum are strongly narrowed anteriorly; anterior edge is ca $0.50-0.60$ times as long as posterior edge; the posterior edge is unmargined; pronotum is as wide as elytra at humeri (Fig. 2A). Synchroa pangu can be distinguished from its congeners on the basis of the following character combination: feebly arcuate lateral sides; anterior edge ca 0.65 times as long as posterior edge; unmargined posterior edge; pronotum narrower than elytra at humeri (Fig. 2B). The lateral sides of the pronotum of Synchroina are somewhat rounded; anterior edge is ca $0.60-0.70$ times as long as posterior edge; posterior edge is unmargined; pronotum is as wide as elytra at humeri (Fig. 2C). Although the shape of pronotum 
in Mallodrya is similar to that in Synchroina, it can be easily separated from other synchroids by distinctly margined posterior edge of pronotum.

07 Elytral striae (Fig. 2I). Nikitsky (1999) used elytral striae as a diagnostic character, followed by Hsiao (2015) and Hsiao et al. (2016). However, elytral striae of synchroids are dark brown and faint, difficult to observe in dried specimens and possibly leading to erroneous observations. To solve this problem, a new examination method has been developed (see Material and methods for details). Furthermore, we confirm that the intraspecific variation of elytral striae is notable after examining more specimens, which varies from obviously present to extremely indistinct (see the detail in description). It suggests that the variations of this character among specimens should not be overestimated for species delimitation in future works.

08 Prosternal process and procoxae. The prosternal process is laminate in Mallodrya, ending just before the posterior edges of procoxae, which is slightly projecting below prosternum and nearly contiguous. In Synchroa and Synchroina, the prosternal process is broad, markedly extending beyond procoxae, which is not projecting below prosternum and separated. The prosternal process is narrowed apically, with rounded apex in Synchroa (excl. S. melanotoides, S. pangu and S. punctata) and Synchroina (Fig. 2E). S. melanotoides, S. pangu and S. punctata have prosternal process with long oval apex (Fig. 2F).

09 Mesoventral cavity and mesometaventral junction. A mesoventral cavity and mesometaventral junction are absent in Mallodrya, but the former is moderately large, shallow and the latter usually a complex fitting in Synchroa and Synchroina. In Synchroa, the mesoventral cavity is distinctly punctate (Fig. 2G) while Synchroina species have smoother mesoventral cavity (Fig. 2H).

10 Pretarsal claws. The pretarsal claws of Synchroa and Mallodrya are simple and serrate in Synchroina.

11 Aedeagus (Fig. 2J). The shape of fused parameres and median lobe are diagnostic for species identification, although Synchroa punctata appears to be similar to S. melanotoides in aedeagus, and intraspecific variation is present in some species (see details in descriptions and figures). The median lobe of Synchroa (excl. S. pangu) is tapered apically, not exceeding from the apex of parameres in natural condition; on the other side $S$. pangu has a slender, elongate and clavate median lobe with an apex, extending over the apex of parameres. In Synchroina, the median lobe is elongate, clavate and slightly narrowed apically, not exceeding the apex of parameres.

\section{Results}

\section{Phylogenetic relationships within Synchroidae}

The heuristic analysis resulted in eight most parsimonious trees (L 53; CI 83; RI 65) and their majority consensus tree (L 54; CI 81; RI 61) is used in the Discussion (Fig. 10). The results suggest four major lineages within Synchroidae including: (1) Mallodrya subaenea; (2) Synchroa spp. (excl. S. pangu); (3) Synchroina spp.; (4) Synchroa pangu. The clade Mallodrya subaenea is the most basal group of this family based on the morphological cladistic analysis, which distinctly differs from other synchroids in appearance (see character analysis). The monophyly of the remaining synchroids is well supported by the following synapomorphies: eyes with long interfacetal setae; unmargined posterior pronotal edge; moderately large and shallow mesoventral cavity; mesometaventral junction with a complex fitting, and their relationship remains unresolved. The clade Synchroa spp. (excl. S. pangu) is supported synapomorphically by eye diameter to interocular space in males ca $1.5-1.7$; pronotum with anterior edge slightly concave and lateral sides strongly narrowed anteriorly; elongate, slender and tapered aedeagal median lobe. The relationships among members of this group are not wellresolved. Synchroina spp. synapomorphically share small body size (ca 6.0-8.5); obliquely truncate apical maxillary palpomere; surface of mesoventral cavity smooth; serrate claws. Moreover, this group is endemic to the Oriental Region. Synchroa pangu is treated as a separated monophyletic group on the 
basis of the following characters: body slender and elongate; pronotum narrower than elytra; anterior edge of the pronotum slightly concave in dorsal view; lateral margins of the pronotum feebly arcuate and unmargined; apex of prosternal process long oval. The character combination suggests that the species should not be placed into any previously established genus and assigned to a new one.

\section{Taxonomy}

\section{Key to the world fauna of Synchroidae Lacordaire, 1859}

(after Nikitsky 1999; Hsiao 2015; Hsiao et al. 2016)

1. Procoxae almost contiguous. North America ....................Mallodrya subaenea Horn, 1888

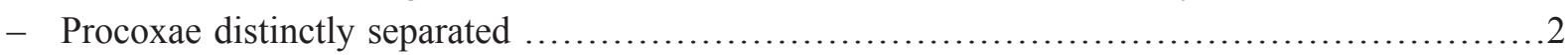

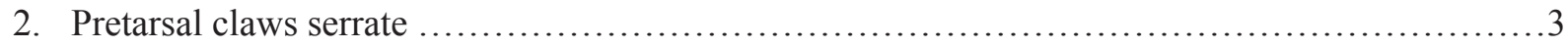

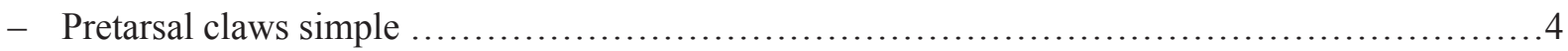

3. Elytra finely and sparsely punctate in apical two-thirds; sutural stria on elytra strongly marked in apical part. Indonesia (Borneo: South Kalimantan) ...Synchroina cuneata (Champion, 1916)

- Elytra densely and coarsely punctate; sutural stria on elytra shallower. Malaysia (Kelantan, Perak, Pahang); Indonesia (West Sumatra, Borneo: South Kalimantan)

Synchroina tenuipennis Fairmaire, 1898

4. Pronotum slightly narrowed anteriorly (Fig. $2 B)$, distinctly narrower than elytra at humeri $(\leq 0.8$ times elytral width at humeri); median lobe of the aedeagus clavate, slender, long, exceeding from the tegmen in natural condition. Mainland China (Sichuan)

Thescelosynchroa pangu (Hsiao, Li, Liu \& Pang, 2016)

- Pronotum strongly narrowed anteriorly (Fig. 2A), nearly as long as elytra at humeri; median lobe of the aedeagus tapered, not extending over the tegmen in natural condition

5. Sides of pronotum almost entirely margined; median part of posterior half of pronotum smooth and impunctate. North America ..................................Synchroa punctata Newman, 1838

- Sides of pronotum unmargined or only partially margined; median part of posterior half of pronotum not smooth. Asia ............................................................. 6

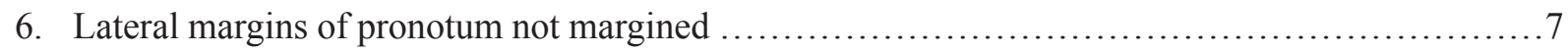

- Lateral margins of pronotum distinctly margined in posterior one-third or one-fourth ...............8

7. Body and legs blackish-brown; parameres slender, basal part of median lobe gradually narrowed apically. Mainland China (Sichuan, Shaanxi, Gansu) .............Synchroa chinensis Nikitsky, 1999

- Body and legs reddish to dark brown; parameres stout, basal one-fourth of median lobe subparallel. Taiwan .... Synchroa formosana Hsiao, 2015

8. Antennae, maxillary palpi blackish-brown; body elongate, slender; prosternal process narrowed apically; aedeagus: parameres stout, wide, with lateral sides subparallel or sinuate. Vietnam; Laos ...... Synchroa elongatula Nikitsky, 1999

- Antennae, legs and maxillary palpi reddish-brown; body stout; prosternal process with long oval apex; aedeagus: parameres slender, with lateral sides gradually narrowed apically 


\author{
Class Hexapoda Blainville, 1816 \\ Order Coleoptera Linnaeus, 1758 \\ Suborder Polyphaga Emery, 1886 \\ Superfamily Tenebrionoidea Latreille, 1802 \\ Family Synchroidae Lacordaire, 1859
}

Genus Synchroa Newman, 1838

Synchroa Newman, 1838: 378. Type species: Synchroa punctata Newman, 1838, by monotypy.

Phaiona Haldeman, 1848: 99. Type species: Phaiona murina Haldeman, 1848.

\title{
Diagnosis
}

This genus is similar to Synchroina and Thescelosynchroa gen. nov.; the differential diagnosis is given in Table 2.

Synchroa punctata Newman, 1838

Figs 3A-B, 4A, G, 5A-B, M, 6A-E

Synchroa punctata Newman, 1838: 378.

\section{Diagnosis}

This species can be easily distinguished from other species of Synchroa by the following combination of characters: body densely covered by pale simple setae; pronotum smooth and impunctate in medio-longitudinal part of posterior half, lateral sides almost entirely margined; prosternal process with long oval apex; aedeagus: parameres moderately narrowed apically, abruptly strongly narrowed at apex.

\section{Material examined}

UNITED STATES OF AMERICA: 3 larvae, Hemlock Draw, Sauk Co., Wisconsin, 43⒉ $21^{\prime} 50^{\prime \prime}$ N, 89 56'49" W, 30 Mar. 2001, D.S. Biggs leg. (YHC); 1 , Hemlock Draw, Sauk Co., Wisconsin, $43^{\circ} 21^{\prime} 46^{\prime \prime}$ N, 89 56'34" W, 11-20 Jun. 2001, Lindgren Funnel Trap, D. Young leg. (YHC); 1 đ, 1 , same locality data as previous, 6-11 Jul. 2001, Lindgren Funnel Trap, D. Young leg. (YHC); 1 , 2 웅, same locality data as previous, 19-25 Jul. 2001, Lindgren Funnel Trap, D. Young leg. (YHC); 1 larva, Merrill, Marathon Co., Wisconsin, 22 Feb. 2003, E. Nowak leg. (YHC); 1 larva, Hemlock Draw, Sauk Co., Wisconsin, 432 $1^{\prime} 46^{\prime \prime}$ N, 89 56'57" W, 21 Apr. 2003, A. Bendlin leg. (YHC); 5 larvae, Otter Creek, Rock Co., Wisconsin, 27 Apr. 2003, A. Bendlin leg. (YHC); 1 ex., West Jefferson, 20 km W of Columbus, Ohio, 6 Jun. 2008, Košt'ál leg. (OKCZ).

CANADA: 1 ex., Warwick Conservation Area, Ontario, 42.995 N, 81.948 W, Jul. 2014, collector unknown (OKCZ); 1 ex., Ottawa, Stittsville, Ontario, 45.275 N, 75.972 W, 3 Jul. 2014, collector unknown (OKCZ); 1 ex., Cornwall, Ontario, 45.04384 N, 74.71467 W, 14 Jul. 2014, collector unknown (OKCZ); 2 ex., Cornwall, Ontario, 45.04384 N, 74.71467 W, 14 Jul. 2014, collector unknown (OKCZ); 2 ex., Merritt island, Ontario, 43.00255 N, 79.241 W, 16 Jul. 2014, collector unknown (OKZC); 1 đ, Boucherville, Québec, 45.55 N, 73.42 W, 21 Aug. 2014, collector unknown (YHC); 1 đૈ, Québec, 46.79416 N, 71.32895 W, 14 Jul. 2015, collector unknown (YHC); 2 ex., Brantford, Ontario, 43.15806 N, 80.35835 W, 27 Jul. 2015, collector unknown (OKCZ).

\section{Redescription}

CoLour. Body and legs completely blackish-brown. Antennae brown in some specimens. 
Table 2. Diagnostic characters among Synchroa Newman, 1838, Synchroina Fairmaire, 1898 and Thescelosynchroa gen. nov.

\begin{tabular}{|c|c|c|c|}
\hline & Synchroa & Synchroina & Thescelosynchroa gen. nov. \\
\hline Size & $\begin{array}{c}\text { Large } \\
\text { (mostly } 10.0-13.0 \mathrm{~mm})\end{array}$ & $\begin{array}{c}\text { Small } \\
(7.0-9.0 \mathrm{~mm})\end{array}$ & $\begin{array}{c}\text { Large } \\
\text { (ca } 10.0 \mathrm{~mm})\end{array}$ \\
\hline Eyes & $\begin{array}{c}\text { Large; ratio of eye } \\
\text { diameter to interocular } \\
\text { space in males ca } \\
1.5-1.7\end{array}$ & \multicolumn{2}{|c|}{$\begin{array}{l}\text { Small; ratio of eye diameter to interocular space in } \\
\text { males ca } 1.8-2.2\end{array}$} \\
\hline $\begin{array}{l}\text { Apical maxillary } \\
\text { palpomere }\end{array}$ & Securiform & Obliquely truncate & Securiform \\
\hline Shape of pronotum & $\begin{array}{l}\text { Lateral sides strongly } \\
\text { narrowed anteriorly }\end{array}$ & $\begin{array}{c}\text { Lateral sides } \\
\text { somewhat rounded, } \\
\text { moderately narrowed } \\
\text { anteriorly }\end{array}$ & Lateral sides feebly arcuate \\
\hline $\begin{array}{l}\text { Greatest width of } \\
\text { pronotum }\end{array}$ & \multicolumn{2}{|c|}{ As wide as elytra at humeri } & $\begin{array}{l}\text { Distinctly narrower than } \\
\text { elytra }\end{array}$ \\
\hline $\begin{array}{l}\text { Surface of } \\
\text { mesoventral cavity }\end{array}$ & Distinctly punctate & Smooth & Distinctly punctate \\
\hline Claws & Simple & Serrate & Simple \\
\hline $\begin{array}{l}\text { Aedeagal median } \\
\text { lobe }\end{array}$ & $\begin{array}{l}\text { Slender and tapered, } \\
\text { not extending the apex } \\
\text { of the tegmen }\end{array}$ & $\begin{array}{l}\text { Elongate and clavate, } \\
\text { not extending the apex } \\
\text { of the tegmen }\end{array}$ & $\begin{array}{l}\text { Elongate and clavate, } \\
\text { extending from the apex of } \\
\text { the tegmen }\end{array}$ \\
\hline
\end{tabular}

Male (Fig. 3A)

MEASUREMENTS. Length: 9.50-11.50 mm; width: 2.25-2.75 mm.

BoDy. Elongate, slightly flattened, elytra rather strongly narrowed posteriorly, covered with pale, elongate and decumbent setae.

HEAD. Eyes lateral, large, emarginate in front of antennal insertions, ratio of eye diameter to interocular space 1.0:1.5-1.7. Antennae filiform, when directed backwards exceeding the humeri of elytra. Scape cylindrical, wider than other antennomeres, pedicel short, antennomere III-XI somewhat clavate, XI longest, length ca 4.5-4.6 times maximum width. Length ratio of antennomeres as follows: $1.90: 1.00: 2.60: 2.45: 2.30: 1.95: 1.85: 2.10: 2.10: 1.90: 3.20$. Apical maxillary palpomere securiform, apical margin moderately rounded, terminal angle somewhat obtuse. Surface lustrous, densely and coarsely punctate; interspaces slightly narrower than puncture diameter.

Pronotum. Truncate anteriorly, anterior edge slightly concave, bisinuate posteriorly, with obtuse median lobe, width ca 1.4-1.5 times as long as length, ca 1.6-1.7 times as wide as head. Lateral sides rounded and strongly narrowed in anterior two-thirds toward head, subparallel in posterior one-third, completely or almost completely margined. Anterior angle rounded; posterior angle rectangular and obtuse. Disc slightly flattened medially, surface lustrous, densely and coarsely punctate; spaces between punctures smaller than puncture diameter. Scutellum width ca 1.50-1.70 times length.

ELYTRA. Elongate, narrowed posteriorly, apex rounded, as wide as pronotal width at humeri, length ca 2.6-2.7 times width, surface lustrous. Disc covered with oval punctures, denser in lateral and basal part; 

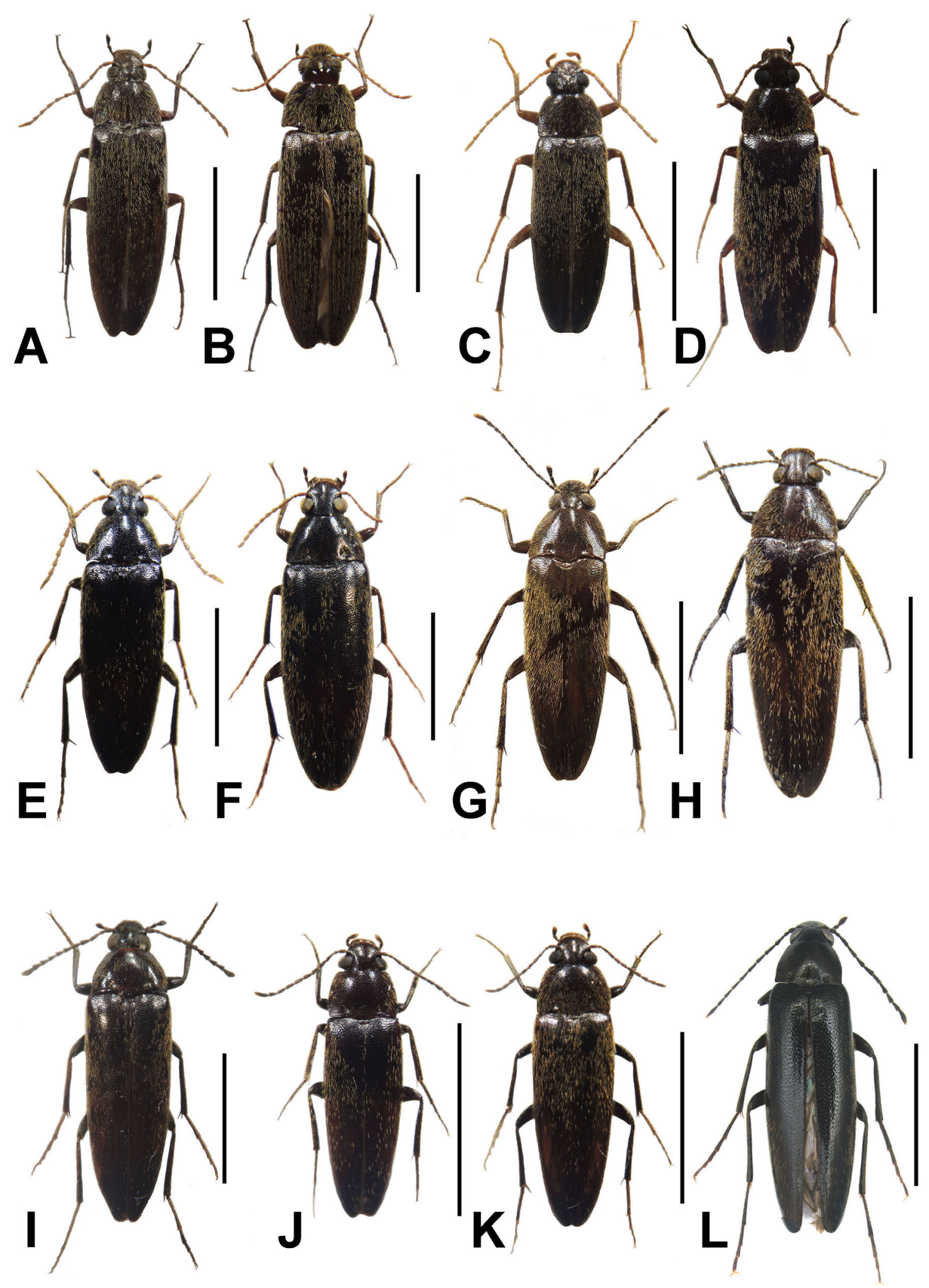

Fig. 3. Habitus, dorsal view. A-B. Synchroa punctata Newman, 1838. C-D. S. melanotoides Lewis, 1895. E-F. S. chinensis Nikitsky, 1999. G-H. S. formosana Hsiao, 2015. I. S. elongatula Nikitsky, 1999. J-K. Synchroina tenuipennis Fairmaire, 1898. L. Thescelosynchroa pangu (Hsiao, Li, Liu \& Pang, 2016) gen. et comb. nov. A, C, E, G, I, J, L = đ. B, D, F, H, K = +. Scale bars: $5.0 \mathrm{~mm}$. 
interspaces wider than puncture diameter. Nine faint traces of striae in each elytron in dorsal view, stria I fused with II (numbered from suture to lateral side) (Fig. 4A), gradually shortened outwards; elytral striae indistinct in some specimens. Prosternum before procoxae about as long as shortest diameter of procoxae. Prosternal process long, margined laterally, long oval, extending well beyond procoxae; length behind procoxae longer than width between procoxae. Width between procoxae ca 0.2 times transverse coxa diameter. Mesoventrite with shallow, oval mesoventral cavity, moderately punctate. Abdominal ventrite V truncate, with lateral sides nearly straight (Fig. 4G); sternite VIII concave in middle of apical edge, forming two rounded lobes on both sides, moderately pubescent apically (Fig. 5B); sternite IX without spiculum gastrale on apical edge (Fig. 5M); tergite VIII without median strut on apical edge, rounded apically, moderately pubescent apically (Fig. 5A); tergite IX and X completely fused, rounded apically, densely pubescent on apical edge (Fig. 5M).

Legs. Slender. Tarsomeres simple, tarsal formula 5-5-4. The longest spur of hind tibiae ca 0.3 times as long as first tarsal segment; length ratio of tarsomeres as follows: $2.30: 1.00: 0.55: 0.85$ (measured without claws). Claws simple.

Aedeagus (Fig. 6A-E). Lanceloate, basal piece curved dorsally, lateral sides roundly arcuate, narrowed basically. Parameres narrowly separated apically with a groove in dorsal median part; lateral sides of the aedeagus almost straight, slightly constricted medially (Fig. 6A-B) or distinctly widened in middle (Fig. 6C), moderately narrowed apically, abruptly strongly narrowed at apex, length ca 3.3-3.5 times maximum width. Median lobe elongate, tapered, strongly narrowed in the apical half.

Female (Fig. 3B)

MEASUREMENTs. Length: 10.00-13.50 mm; width: 2.50-3.00 mm.

Body. Similar to male.

HeAd. Eyes smaller than in male, ratio of eye diameter to interocular space 1.0:1.9-2.0. Antennae shorter in male, when directed backwards extending the posterior edge of pronotum, antennomere XI ca 3.6-3.7 times as long as maximum width. Length ratio of antennomeres as follows: $1.50: 1.00: 2.85: 2.00: 1.70: 1.90: 1.70: 1.75: 1.70: 1.75: 2.85$.

Pronotum. Ca 1.5 times wider than length, ca 1.7 times as wide as head.

ELYTRA. Slightly wider than in male, as wide as pronotal width at humeri, length ca $2.5-2.6$ times width.

OviPositor. Paraproct elongate, ca 3.1-3.2 times length of coxite, sides straight and subparallel; proctiger subtruncate.

\section{Notes}

This species is fairly common in eastern North America, found on tree bark or attracted to light. It can also be collected using Malaise or Lindgren funnel traps. Larvae develop in the moist environment beneath the bark of decaying woods (Payne 1931; Young 1991, 2002; Majka \& Pollock 2006; Ślipiński \& Lawrence 2010).

\section{Distribution}

Eastern North America: USA, Canada. 

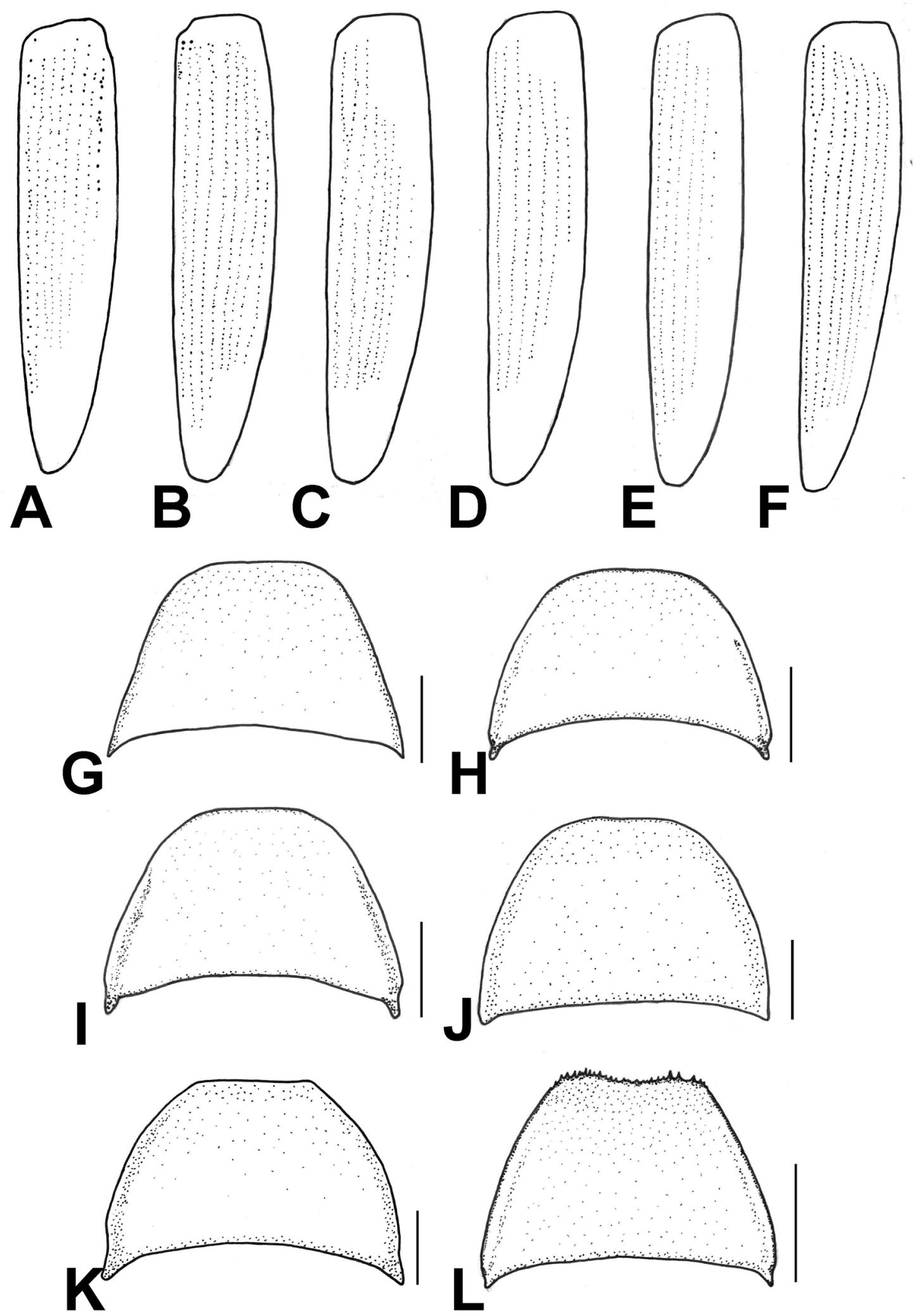

Fig. 4. Elytron and abdominal ventrite V. A-F. Elytron. G-L. Abdominal ventrite $\mathrm{V}$ of $\hat{\partial} \hat{\jmath}$. $-\mathbf{A}$, G. Synchroa punctata Newman, 1838. B, H. S. melanotoides Lewis, 1895. C, I. S. chinensis Nikitsky, 1999. D, J. S. formosana Hsiao, 2015. E, K. S. elongatula Nikitsky, 1999. F, L. Synchroina tenuipennis Fairmaire, 1898. Scale bars: $0.5 \mathrm{~mm}$. 

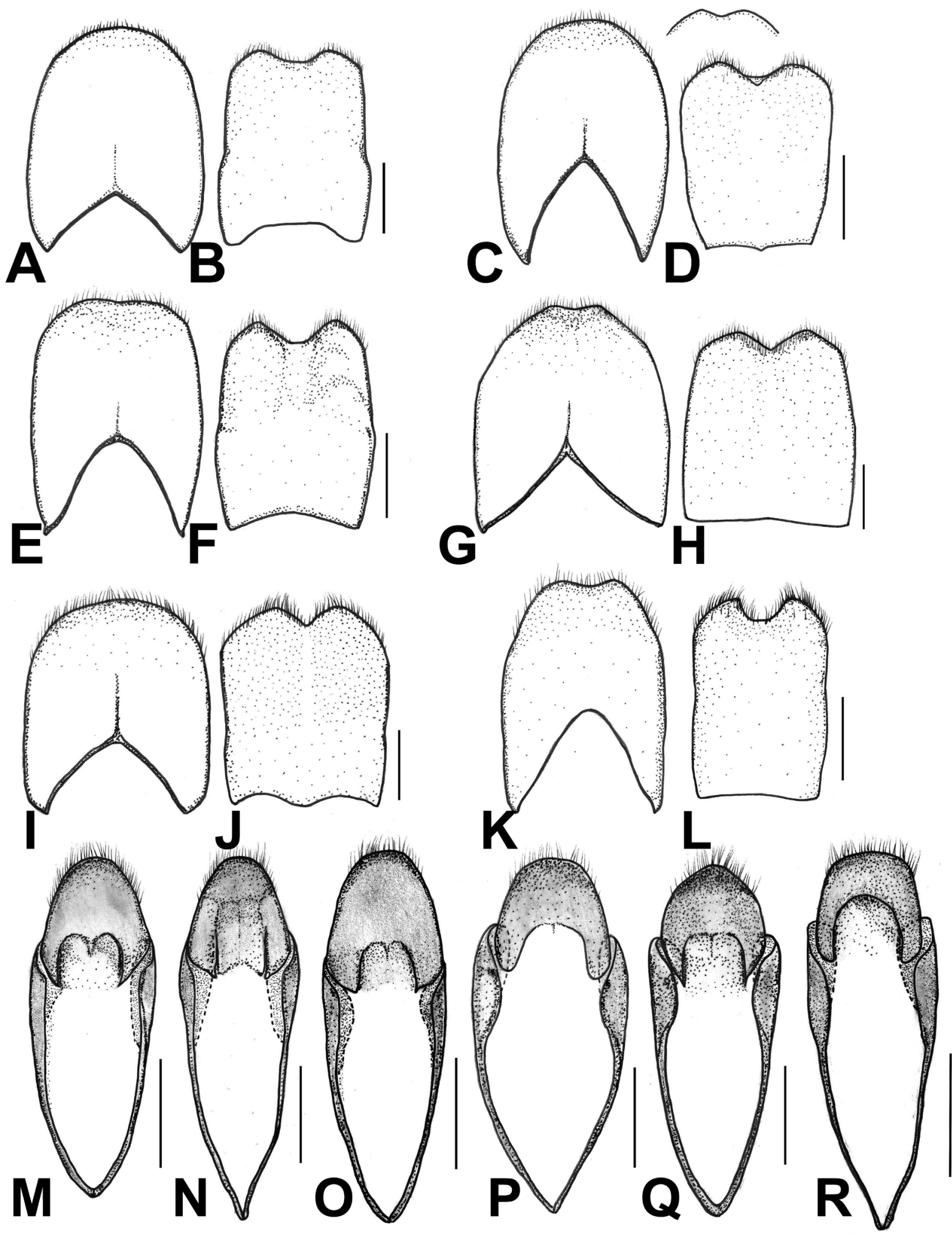

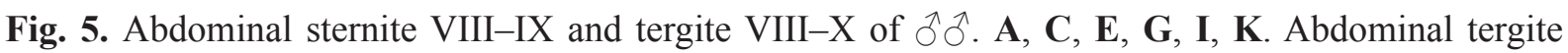
VIII. B, D, F, H, J, L. Abdominal sternite VIII. M-R. Abdominal sternite IX, and fused tergite IX and X. - A-B, M. Synchroa punctata Newman, 1838. C-D, N. S. melanotoides Lewis, 1895. E-F, O. S. chinensis Nikitsky, 1999. G-H, P. S. formosana Hsiao, 2015. I-J, Q. S. elongatula Nikitsky, 1999. K-L, R. Synchroina tenuipennis Fairmaire, 1898. Scale bars: $0.5 \mathrm{~mm}$. 

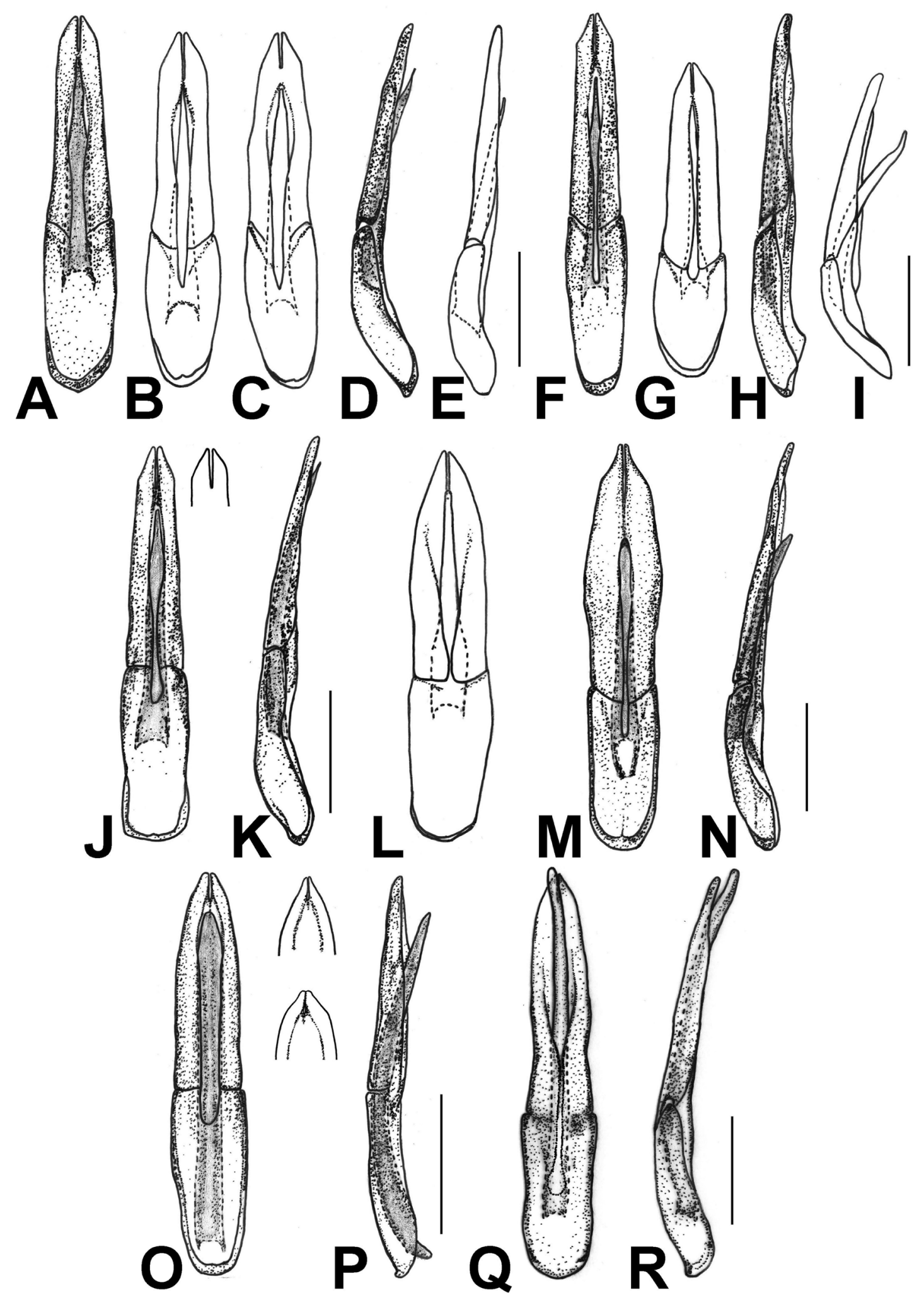

Fig. 6. Aedeagus. A-E. Synchroa punctata Newman, 1838. F-I. S. melanotoides Lewis, 1895. J-K. S. chinensis Nikitsky, 1999. L. S. formosana Hsiao, 2015. M-N. S. elongatula Nikitsky, 1999. O-P. Synchroina tenuipennis Fairmaire, 1898. Q-R. Thescelosynchroa pangu (Hsiao, Li, Liu \& Pang, 2016) gen. et comb. nov. - A-C, F-G, J, L-M, O, Q. Dorsal view. D-E, H-I, K, N, P, R. Lateral view. Scale bars: $0.5 \mathrm{~mm}$. 
Synchroa melanotoides Lewis, 1895

Figs 3C-D, 4B, H, 5C-D, N, 6F-I

Synchroa melanotoides Lewis, 1895: 263.

\section{Diagnosis}

This species resembles Synchroa elongatula Nikitsky, 1999 in pronotal configuration with lateral sides of the pronotum margined in posterior one-third to one-fourth, but it can be also separated by its reddishbrown antennae and legs; stout elytra; prosternal process with long oval apex; aedeagus: paramere more slender, with lateral sides gradually narrowed apically. It resembles $S$. punctata in the shape of the aedeagus, but can be separated in the body being closely covered with yellowish simple setae; eyes larger; pronotum margined in posterior one-third to one-fourth of lateral sides; prosternal process thinner; dorsal groove of aedeagus narrower basally.

\section{Material examined}

JAPAN: 1 ex., Matsum, date and collector unknown (HUM); 1 ô, Kuzukawa, Hiraka-cho, Aomori Pref., 10 Aug. 1957, K. Shimoyama leg. (NMNS); 2 우, 1 ex., Kuzukawa, Hiraka-cho, Aomori Pref., 18 Aug. 1957, K. Shimoyama leg. (NMNS); 1 q, Kuzukawa, Hiraka-cho, Aomori Pref., 20 Aug. 1957, K. Shimoyama leg. (NMNS); 1 ô, Kuzukawa, Hiraka-cho, Aomori Pref., 21 Aug. 1957, K. Shimoyama leg. (NMNS); 1 ㅇ, Mennoki-toge, Tsugu, Aichi Pref., 27-28 Jul. 1974, H. Yamada leg. (NMNS); 1 ○, Kamitakara-mura, Gifu Pref., 11 Aug. 1979, M. Satô leg. (NMNS); 1 +, Ohboshi-yama, Tsushima, 30 Jun. 1980, N. Ohbayashi leg. (NMNS); 1 ex., Taniyama, Ohno-shi, Fukui Pref., 5-6 Aug. 1984, M. Saitô leg. (OKCZ); 1 ex., Kobiyaku Imaichi, Tochigi Pref., 20 Jul. 1986, K. Emoto leg. (OKCZ); 1 ex., Mt. Gomadan-zan, Ryûjin-mura, Hidaka-gun, Wakayama Pref., 10 Jul. 1988, H. Miyazaki leg. (OKCZ); 2 ex., Uchinokaya, Ina-shi, Nagano Pref., collected on host (Juglans mandshurica var. sachalinensis) 1 May 1990, emerged 11-13 Jun. 1990, R. Toyoshima leg. (OKCZ); 2 ex., Mt. Asuwa, Fukui-shi, Fukui Pref., 18 Jun. 1994, M. Saitô leg. (OKCZ); 1 ex., Jyôzan-kei, Minami-ku, Sapporoshi, Hokkaido, 7 Aug. 2008, R. Toyoshima leg. (OKCZ); 1 q, Fushimiinari, Fushimi, Kyoto Pref.,

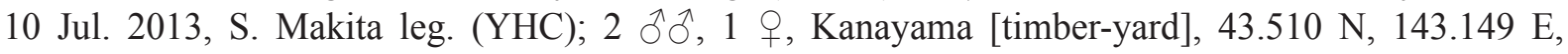
Mianmifurano-chô, Sorachi-gun, Hokkaido, 4 Aug. 2016, N. Kikuchi leg. (YHC).

\section{Redescription}

Colour. Body completely blackish-brown. Antennae and legs somewhat reddish-brown.

Male (Fig. 3C)

MeAsurements. Length: $8.25-10.50 \mathrm{~mm}$; width: 2.00-2.5 mm.

BoDy. Elongate, slightly flattened, elytra rather strongly narrowed posteriorly, covered with yellowish, elongate and decumbent setae.

HEAD. Eyes lateral, large, emarginate in front of antennal insertions, ratio of eye diameter to interocular space $1.0: 1.2-1.3$. Antennae filiform, when directed backwards exceeding the humeri of elytra. Scape cylindrical, wider than other antennomeres, pedicel short, antennomere III-XI somewhat clavate, XI longest, length ca 3.1-4.1 times maximum width. Length ratio of antennomeres as follows: $1.60: 1.00: 2.60: 2.50: 2.10: 2.10: 2.05: 2.05: 1.85: 1.75: 2.85$. Apical maxillary palpomere securiform, apical margin moderately rounded, terminal angle somewhat obtuse. Surface lustrous, densely and coarsely punctate; interspaces slightly narrower than puncture diameter.

Pronotum. Truncate anteriorly, anterior edge slightly concave, bisinuate posteriorly, with obtuse median lobe, width ca 1.4-1.5 times length, ca 1.5-1.6 times as wide as head. Lateral sides rounded and strongly 
narrowed in anterior two-thirds toward head, subparallel in posterior one-third, margined in posterior one-third to one-fourth. Anterior angle rounded; posterior angle rectangular and obtuse. Disc slightly flattened medially, surface lustrous, densely and coarsely punctate; spaces between punctures smaller than puncture diameter. Scutellum width ca 1.4-1.6 times length.

ELYTRA. Elongate, narrowed posteriorly, apex rounded, as wide as pronotal width at humeri, length ca 2.4-2.6 times width, surface lustrous. Disc covered with oval punctures, denser in lateral and basal part; interspaces wider than puncture diameter. Nine faint traces of striae in each elytron from dorsal view, stria I fused with II (Fig. 4B), gradually shortened outwards, elytral striae indistinct in some specimens. Prosternum before procoxae about as long as shortest diameter of procoxae. Prosternal process long, margined laterally, long oval; length behind procoxae shorter than or as long as width between procoxae. Width between procoxae ca 0.2 times transverse coxa diameter. Mesoventrite with shallow, oval mesoventral cavity, moderately punctate. Abdominal ventrite $\mathrm{V}$ subtruncate, with lateral sides nearly straight to slightly rounded (Fig. 4H); sternite VIII concave in middle of apical edge, forming two roundly angular lobes on both sides, moderately pubescent apically (Fig. 5D); sternite IX without spiculum gastrale on apical edge (Fig. 5N); tergite VIII without median strut on apical edge, rounded apically or emarginate in middle, moderately pubescent apically (Fig. 5C); tergite IX and X completely fused, rounded apically, densely pubescent on apical edge (Fig. $5 \mathrm{~N}$ ).

Legs. Slender. Tarsomeres simple, tarsal formula 5-5-4. The longest spur of hind tibiae ca 0.2 times as long as first tarsal segment; length ratio of tarsomeres as follows: $2.10: 1.00: 0.50: 0.70$ (measured without claws). Claws simple.

Aedeagus (Fig. 6F-I). Lanceloate, basal piece curved dorsally, lateral sides roundly arcuate, narrowed basically. Parameres narrowly separated apically and with a groove in dorsal median part, lateral sides straight, slightly narrowed apically, abruptly strongly narrowed at apex, length ca 3.0-3.9 times maximum width. Median lobe elongate, tapered, strongly narrowed apically in apical half.

Female (Fig. 3D)

MEASUREMENTS. Length: $10.25-12.00 \mathrm{~mm}$; width: $2.5-3.25 \mathrm{~mm}$.

Body. Similar to males.

HeAd. Eyes smaller than in male, ratio of eye diameter to interocular space 1.0:1.4-1.5. Antennae shorter in male, when directed backwards extending the posterior edge of pronotum, antennomere XI ca 2.8 times as long as maximum width. Length ratio of antennomeres as follows: $1.90: 1.00: 2.10: 2.30: 2.25: 2.10: 2.10: 2.05: 2.00: 1.90: 2.60$.

Pronotum. Ca 1.5 times wider than length, ca 1.5-1.6 times as wide as head.

ELYTRA. Slightly wider than in male, as wide as pronotal width at humeri, length ca 2.5 times width.

Ovipositor. Paraproct elongate, ca 3.0 times length of coxite, sides straight and subparallel; proctiger subtruncate.

\section{Notes}

This is a common species in Japan, which can be captured at light (S. Makita, personal communication). Larvae can be collected under the bark of decaying oak wood (Hayashi 1975) and walnut trees, Juglans mandshurica var. sachalinensis. Nikitsky (1999) mentioned that antennomere XI of this species is ca 2.5-2.8 times as long as the width, whose data were followed by Hsiao (2015) and Hsiao et al. (2016). However, our examination shows that this species has a wider variation in the length of antennomere XI than previously documented. 


\section{Distribution}

Russia (Far East); Japan; Korea; China (Jilin) (Löbl 2008).

\section{Notes}

Nikitsky (1999) and Löbl (2008) indicated this species as present in Korea; these data were neglected by Hsiao (2015) and Hsiao et al. (2016). Thus, we herein list Korea in the distribution. Additionally, Löbl (2008) referred to China (Jilin prov.); however, we cannot find any further literature or specimen to confirm this assumption.

Synchroa chinensis Nikitsky, 1999

Figs 3E-F, 4C, I, 5E-F, O, 6J-K, 7

Synchroa chinensis Nikitsky, 1999: 478.

\section{Diagnosis}

This species resembles Synchroa formosana Hsiao, 2015 by the unmargined lateral sides of pronotum, but can be distinguished by the following combination of characters: blackish-brown body and reddishbrown to dark brown antennae, apical maxillary palpomere and tarsi; aedeagus: more slender paramere and narrower basal part of median lobe.

\section{Material examined}

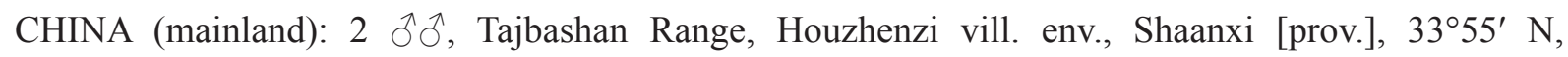
107²4' E, 1900 m, 15 Aug.-15 Oct. 1999, collector unknown (OKZC); 1 ex., 15 km south of Shouman, Daba Shan Mts, Shaanxi Prov., 32 ${ }^{\circ} 8^{\prime}$ N, 108 37' E, 1800-2100 m, 25 May-14 Jul. 2000, A. Plutenko leg. (OKCZ); 1 क , Lueyang, Shaanxi prov., 23-30 May 2009, E. Kučera leg. (MAIC); 1 q, Qingchenghou Shan Mts, 70 km NW of Chengdu, Sichuan prov., 1500 m, 6-13 Aug. 2010, S. Murzin leg. (OKZC); 4 ईิे, 1 क , Nanping (Jiunaigou) [=Jiuzhaigou] env., Sichuan prov., $1700 \mathrm{~m}, 33.2435$

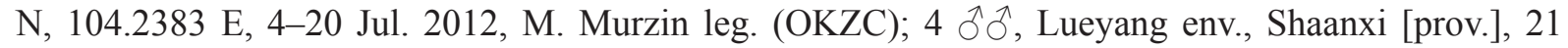
Jun.-6 Jul. 2014, E. Kučera leg. (OKZC); 1 +, 100 km S of Jayuguan, Tulai env., NW of Gansu [prov.], 4200 m, 10 Jul. 2014, V. Patrikeev leg. (OKZC).

\section{Redescription}

Colour. Body and legs blackish-brown. Antennae, apical maxillary palpomere and tarsi reddish brown to dark brown.

\section{Male (Fig. 3E)}

MEASUREMENTS. Length: 9.25-13.25 mm; width: 2.25-3.50 mm.

BoDy. Elongate, slightly flattened, elytra rather strongly narrowed posteriorly, covered with yellowish, elongate and decumbent setae.

HEAD. Eyes lateral, large, emarginate in front of antennal insertions, ratio of eye diameter to interocular space $1.0: 1.3-1.5$. Antennae filiform, when directed backwards exceeding the humeri of elytra. Scape cylindrical, wider than other antennomeres, pedicel short, antennomere III-XI somewhat clavate, XI longest, length ca 4.3-5.6 times maximum width. Length ratio of antennomeres as follows: $1.50: 1.00: 2.25: 2.10: 1.85: 1.95: 1.95: 1.90: 1.85: 1.60: 2.75$. Apical maxillary palpomere securiform, apical margin moderately rounded, terminal angle somewhat obtuse. Surface lustrous, densely and coarsely punctate; interspaces slightly narrower than puncture diameter. 
Pronotum. Truncate anteriorly, bisinuate posteriorly, with obtuse median lobe, width ca 1.5 times length, ca 1.6-1.7 times as wide as head. Lateral sides slightly rounded and strongly narrowed in anterior twothirds toward head, subparallel in posterior one-third, unmargined. Anterior angle rounded; posterior angle rectangular and obtuse. Disc slightly flattened medially, surface lustrous, densely and coarsely punctate; spaces between punctures smaller than puncture diameter. Scutellum with width ca 1.6-1.7 times length.

ELYTRA. Elongate, narrowed posteriorly, apex rounded, as wide as pronotal width at humeri, length ca 2.4-2.7 times width, surface lustrous. Disc covered with oval punctures, denser in lateral and basal part; interspaces wider than puncture diameter. Eight faint traces of striae in each elytron from dorsal view, stria I fused with II (Fig. 4C), gradually shortened outwards, only four traces of elytral striae present or extremely indistinct in some specimens. Prosternum before procoxae about as long as shortest diameter of procoxae. Prosternal process long, margined laterally, rounded and narrowed apically; length behind procoxae longer than width between procoxae. Width between procoxae ca 0.3 times transverse coxa diameter. Mesoventrite with shallow, oval mesoventral cavity, moderately punctate. Abdominal ventrite V subtruncate, with lateral sides somewhat rounded (Fig. 4I); sternite VIII concave in middle of apical edge, forming two roundly angular lobes on both sides, densely pubescent apically (Fig. 5F); sternite IX without spiculum gastrale on apical edge (Fig. 5O); tergite VIII without median strut on apical edge, rounded apically or slightly emarginate in middle, moderately pubescent apically (Fig. 5E); tergite IX and X completely fused, rounded apically, densely pubescent on apical edge (Fig. 5O).

Legs. Slender. Tarsomeres simple, tarsal formula 5-5-4. The longest spur of hind tibiae ca 0.3 times as long as first tarsal segment; length ratio of tarsomeres as follows: $2.35: 1.00: 0.55: 0.85$ (measured without claws). Claws simple.

Aedeagus (Fig. 6J-K). Lanceloate, basal piece curved dorsally, lateral sides narrowed basically. Parameres narrowly separated apically and with a groove in dorsal median part, lateral sides slightly sinuate, moderately narrowed apically, abruptly strongly narrowed at apex, length ca 3.5-3.9 times maximum width. Median lobe elongate, tapered, strongly narrowed apically in apical half.

Female (Fig. 3F)

MEASUREMENTS. Length: $9.50-13.00 \mathrm{~mm}$ (11.50 in holotype); width: $2.25-3.25 \mathrm{~mm}$.

BoDy. Similar to males.

HEAD. Eyes smaller than in male, ratio of eye diameter to interocular space 1.0:1.2-1.5 (1.49 in holotype). Antennae shorter in male, when directed backwards extending the posterior edge of pronotum, antennomere XI ca 2.9 times as long as maximum width. Length ratio of antennomeres as follows: $2.20: 1.00: 2.10: 1.90: 1.85: 1.90: 2.00: 1.90: 1.80: 1.80: 2.40$.

Pronotum. Ca 1.5-1.6 times wider than length (1.5 in holotype), ca 1.5-1.6 times as wide as head.

Elytra. Slightly wider than in male, as wide as pronotal width at humeri, length ca 2.4-2.5 times width (2.6-2.7 in holotype).

OviPositor. Paraproct elongate, ca 2.6-3.0 times length of coxite, sides straight and subparallel; proctiger subtruncate.

\section{Remarks}

In the original description, Nikitsky (1999) provided as diagnostic character the presence of faint striae only in apical part and illustrated it. This character together with the posteriorly narrowed elytra has been used in Hsiao (2015) and Hsiao et al. (2016) as comparative information to distinguish S. formosana. 
However, in the course of this study we discovered that the elytral striae are variable, noticeable on the entire elytron or even indistinct in some specimens. Elytral striae of synchroids are vague and difficult to observe accurately if the specimen is dry and not dissected, consequently it is possible that the elytral striae of the holotype have not been not observed correctly. After examining a large number of specimens, the shape of the elytra appears proved to be variable as well (length ca 2.4-2.7 times width). Therefore, we eliminate both inappropriate characters from the diagnosis and re-diagnose the differences between the species (see the detail in diagnosis and key).

\section{Distribution}

China (Sichuan, Shaanxi, Gansu) (Fig. 7).

\section{Notes}

This species was described based on a single female from Qingchengshan in Sichuan Province. On the basis of new available specimens $S$. chinensis is confirmed as a valid species, distributed in Shaanxi and Gansu province.

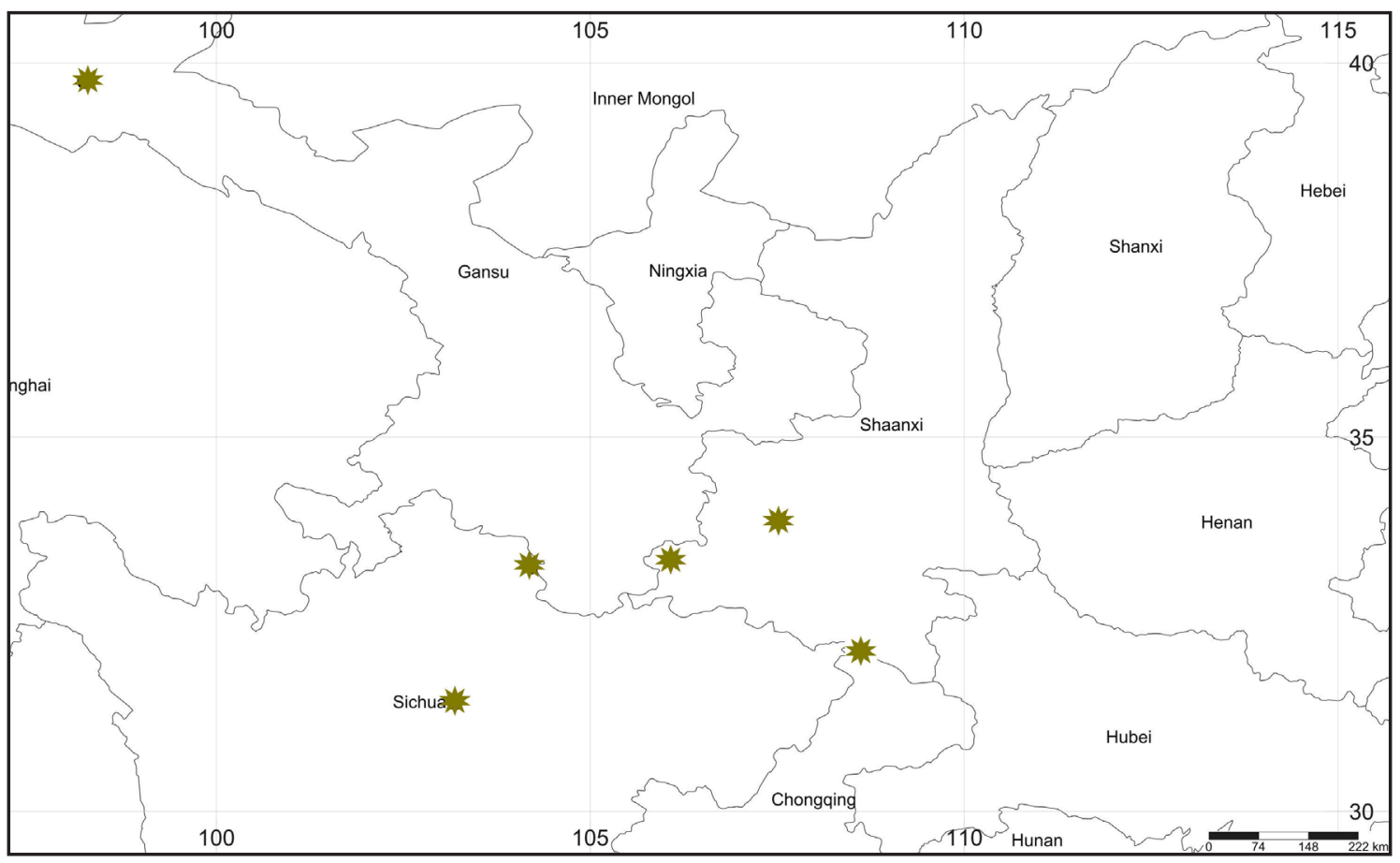

Fig. 7. Distribution map of Synchroa chinensis Nikitsky, 1999 from China. 
Synchroa formosana Hsiao, 2015

Figs 3G-H, 4D, J, 5G-H, P, 6L, 8

Synchroa formosana Hsiao, 2015: 244.

\section{Diagnosis}

This species is similar to Synchroa chinensis Nikitsky, 1999 in possessing unmargined lateral sides of pronotum, but can be distinguished by the following combination of characters: reddish-brown to brown body and legs; aedeagus: wider and more rounded paramere and wider basal part of median lobe.

\section{Material examined}

Holotype (Fig. 3G)

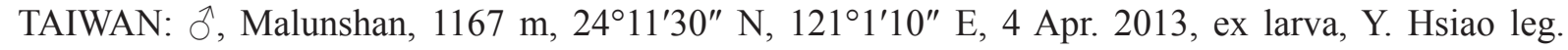
(NMNS).

\section{Paratype}

TAIWAN: 1 ex., same data as for holotype (NMNS).

\section{Other material}

TAIWAN: 1 q, Fushan, Ilan Co., 29 May 1995, light trap, site C, 2000, A. Warneke leg. (TFRI); 1 ô, Tengchih, Kaoshiang, 18 Aug. 2008, C.-T. Yao leg. (TARI); 1 , Ssumahsien Trail, Miaoli, 9 Jul. 2011, Y.-L. Lin leg. (TARI); 1 q, Fenchihu, Chiayi, 4 Sep. 2012, C.-F. Lee leg. (TARI); 1 $\lesssim$, Dalulintao [= Dalu Forest Trail], Wufeng, Hsinchu, 1 Jul. 2017, Y.-L. Lin leg. (YHC).

\section{Supplementary description of male}

AвDomen. Abdominal ventrite $\mathrm{V}$ subtruncate, with lateral sides somewhat rounded, terminal margin slightly emarginate in middle (Fig. 4J); sternite VIII concave in middle of apical edge, forming two roundly angular lobes on both sides, densely pubescent apically (Fig. 5H); sternite IX without spiculum gastrale on apical edge (Fig. 5P); tergite VIII without median strut on apical edge, emarginate in middle, moderately pubescent apically (Fig. 5G); tergite IX and X completely fused, rounded apically, densely pubescent on apical edge (Fig. 5P).

\section{Supplementary description of female (Fig. $3 \mathrm{H}$ )}

MAESUREMENTs. Length: 10.90-13.00 mm; width: 2.95-3.35 mm.

Body. Similar to males.

HEAD. Eyes smaller than in male, ratio of eye diameter to interocular space 1.0:1.6-2.0. Antennae shorter in male, when directed backwards extending the posterior edge of pronotum, antennomere XI ca 3.3-4.0 times as long as maximum width. Length ratio of antennomeres as follows: $2.00: 1.00: 2.30: 2.00: 2.10: 2.00: 1.90: 2.00: 2.10: 2.00: 2.85$.

Pronotum. Ca 1.5 times as wide as length, ca 1.7-1.8 times as wide as head.

ELYTRA. Slightly wider than in male, as wide as pronotal width at humeri, length ca 2.6-2.7 times width.

OviPositor. Paraproct elongate, ca 2.7-3.0 times length of coxite, sides straight and subparallel; proctiger subtruncate. 


\section{Notes}

Although this species was described as having elytral striae in the basal half of the elytron, we discovered that the elytral striae are noticeable on the entire elytron (Fig. 4D) or indistinct in some specimens. Besides, elytral striae on each elytron vary from 4-7 traces in this species. On the other hand, we examined one specimen having narrower apical half of paramere than the holotype (Fig. 6L). After examination of the external morphological characters and the median lobe of the aedeagus, and in consideration of the intraspecific variation of other synchroids, we herein conclude that it is conspecific with S. formosana.

\section{Distribution}

Taiwan (Fig. 8).

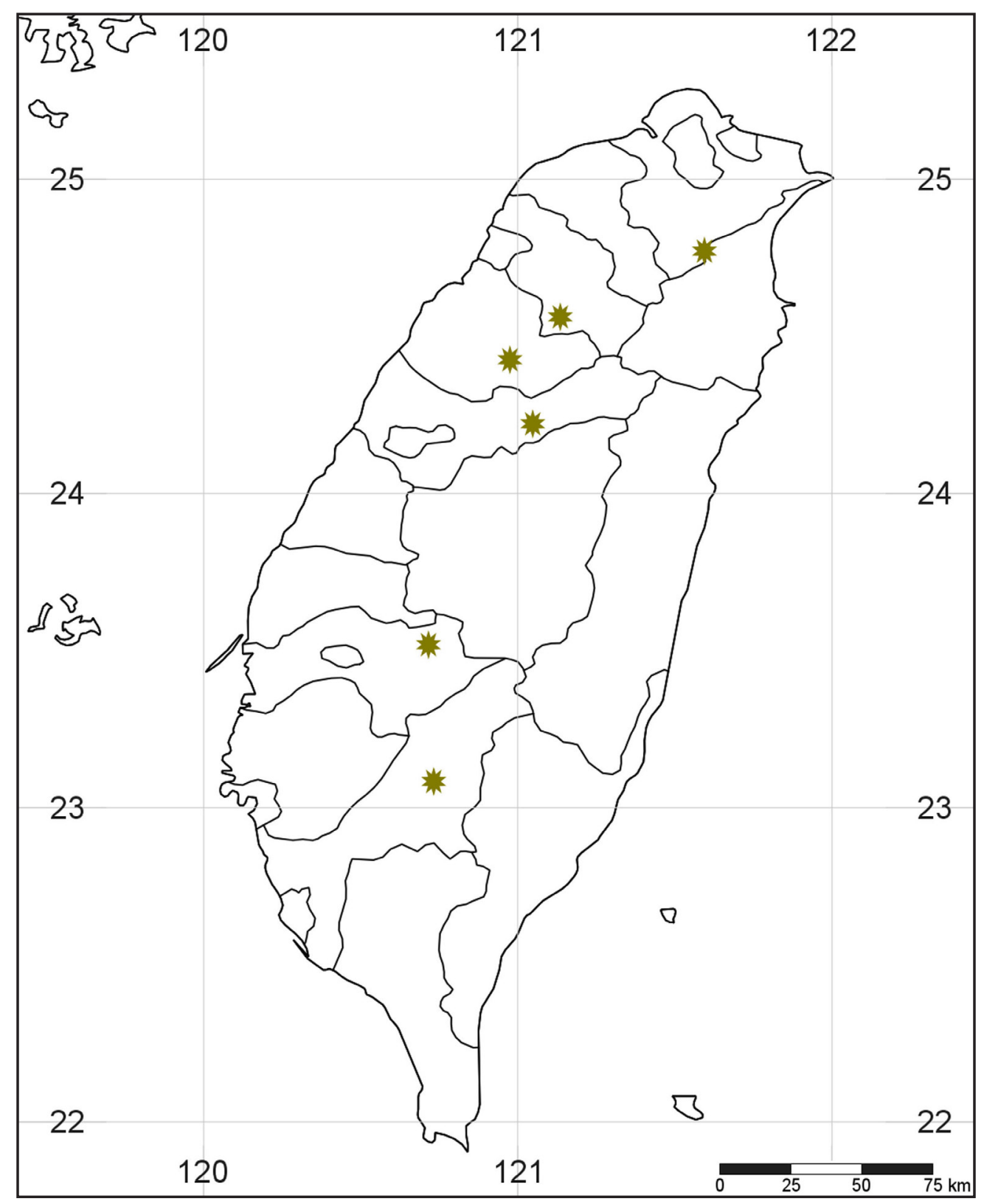

Fig. 8. Distribution map of Synchroa formosana Hsiao, 2015 from Taiwan. 
Synchroa elongatula Nikitsky, 1999

Figs 3I, 4E, K, 5I-J, Q, 6M-N

Synchroa elongatula Nikitsky, 1999: 476.

\section{Diagnosis}

This species resembles Synchroa melanotoides in pronotal structure, with lateral sides margined in posterior one-third to one-fourth, but it can be distinguished by its blackish brown antennae and legs; elongate and slender elytra; prosternal process narrowed apically; aedeagus: paramere wider, with lateral sides subparallel or sinuate. It is also similar to $S$. formosana, but differs in partially margined pronotum; aedeagus: basal part of median lobe narrower.

\section{Material examined}

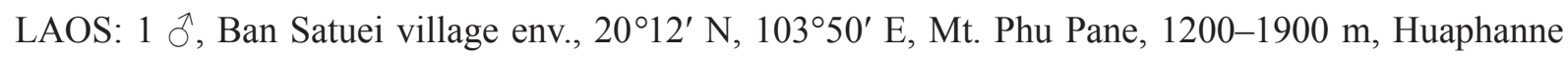
prov. [= Houaphanh prov. in NE Laos], 1-20 May 2014, St. Jakl and Lao leg. (OKZC).

Supplementary description of male from Laos (Fig. 3I)

MeAsurements. Length: $11.50 \mathrm{~mm}$ (10.00-11.00 in type series); width: $3.00 \mathrm{~mm}$.

HEAD. Ratio of eye diameter to interocular space 1.0:1.6 (1.41-1.49 in type series). Antennomere XI ca 3.0 times as long as maximum width. Length ratio of antennomeres as follows: $1.65: 1.00: 2.10: 1.95: 1.50: 1.50: 1.40: 1.50: 1.55: 1.50: 2.20$.

Pronotum. Ca 1.5 times wider than length, ca 1.7 times as wide as head.

ELYTRA. Ca 3.0 times as long as maximum width. Seven faint traces of striae in each elytron from dorsal view, stria I fused with II (Fig. 4E), gradually shortened outwards. Prosternal process long, margined laterally, rounded and narrowed apically; length behind procoxae longer than width between procoxae. Mesoventrite with shallow, oval mesoventral cavity, moderately punctate. Abdominal ventrite $\mathrm{V}$ truncate, with lateral sides rounded (Fig. 4K); sternite VIII concave in middle of apical edge, forming two roundly angular lobes on both sides, densely pubescent apically (Fig. 5J); sternite IX without spiculum gastrale on apical edge (Fig. 5Q); tergite VIII without median strut on apical edge, rounded apically, densely pubescent apically (Fig. 5I); tergite IX and X completely fused, rounded apically, densely pubescent on apical edge (Fig. 5Q).

Aedeagus (Fig. 6M-N). Lanceloate, basal piece curved dorsally, lateral sides narrowed basically. Parameres narrowly separated apically and with a groove in dorsal median part, lateral sides distinctly widened in middle, length ca 3.2 times maximum width. Median lobe elongate, tapered, strongly narrowed apically in apical half.

\section{Notes}

In the original description, this species was mentioned as having striae only in the apical part of the elytral suture. However, we discovered extremely indistinct elytral striae on this specimen. Together with our analysis of this character, it is possible that the elytral striae of the type series are too faint to observe or this character varies from absent to indistinct within this species. On the other hand, although most of the characters are in accordance with the original description, the parameres of this specimen are different from the illustration given in Nikitsky (1999) by its distinctly widened lateral sides and narrower dorsal groove, which implies that it could belong to another taxon new to science. Considering the insufficient material, intraspecific variation within other species and geographic distribution, we herein regard this specimen as representing a variation of $S$. elongatula instead of giving it a new taxonomic status. 


\section{Distribution}

Vietnam; Laos, new record.

Genus Synchroina Fairmaire, 1898

Synchroina Fairmaire, 1898: 399. Type species: Synchroa tenuipennis Fairmaire, 1898, by monotypy.

\section{Diagnosis}

This genus is similar to Synchroa and Thescelosynchroa gen. nov.; the differential diagnosis is given in Table 2.

\section{Synchroina tenuipennis Fairmaire, 1898}

Figs $3 \mathrm{~J}-\mathrm{K}, 4 \mathrm{~F}, \mathrm{~L}, 5 \mathrm{~K}-\mathrm{L}, \mathrm{R}, 6 \mathrm{O}-\mathrm{P}, 9$

Synchroina tenuipennis Fairmaire, 1898: 399.

Synchroa malaccana Pic, 1917: 14.

\section{Diagnosis}

This species resembles Synchroina cuneata (Champion, 1916), but can be distinguished by the following combination of characters: elytra densely and coarsely punctate, spaces between punctures mostly less than 0.5 times puncture diameter; sutural stria on elytra shallower; aedeagus: basal piece ca $0.7-0.9$ times parameres (Champion 1916; Nikitsky 1999).

\section{Material examined}

MALAYSIA: 1 ð, Korbu mt., Banjaran Titi Wangsa mts, 25 km NE of IPOH, Perak, 1200 m, 27 Jan.-2 Feb. 1999, P. Čechovský leg. (OKZC); 1 đ̃, Korbu mt., Banjaran Titi Wangsa mts, 25 km NE of IPOH, Perak, 1200 m, 1-15 Apr. 2000, P. Čechovský leg. (OKZC); 1 + , Tanah Rata env., gun. Jasar,

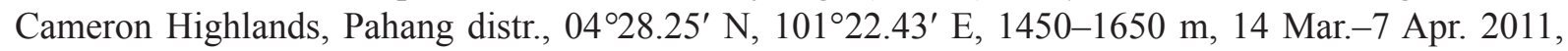

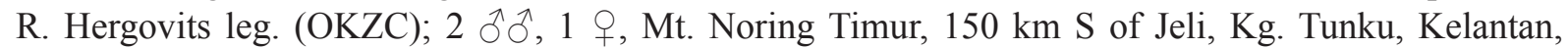
1200 m, 21 Feb.-14 Mar. 2013, P. Čechovský leg. (OKZC); 1 §, Kampong Perias, Mt. Chamah, 70 km NW of Gua Musang, Kelantan, 1900 m, 17 Apr.-9 May. 2014, P. Čechovský leg. (OKZC).

INDONESIA: 1 đ̄, Solok, W. Sumatra, Sep. 1995, unknown collector (OKZC); 1 , Haratai env., Loksado, 246'58" S, 115³3'19" E, S Kalimantan, 13-17 Oct. 2014, R. Gabriš leg. (OKZC).

\section{Redescription}

Colour. Body and legs reddish-brown to blackish-brown.

Male (Fig. 3J)

MeAsuRements. Length: $6.50-9.25 \mathrm{~mm}$; width: $1.50-2.25 \mathrm{~mm}$.

BoDy. Elongate, slightly flattened, elytra rather strongly narrowed posteriorly, covered with yellowish, elongate and decumbent setae.

HEAD. Eyes lateral, large, emarginate in front of antennal insertions, ratio of eye diameter to interocular space 1.0:1.8-2.0. Antennae filiform, when directed backwards exceeding the humeri of elytra. Scape cylindrical, wider than other antennomeres, pedicel short, antennomere III-XI somewhat clavate, XI longest, length ca 3.5-4.4 times maximum width. Length ratio of antennomeres as follows: $1.65: 1.00: 2.25: 2.10: 1.90: 2.00: 2.05: 2.05: 2.10: 1.90: 2.50$. Apical maxillary palpomere securiform, 
apical margin rounded, terminal angle somewhat obliquely truncate. Surface lustrous, densely and coarsely punctate; interspaces slightly narrower than puncture diameter.

Pronotum. Truncate anteriorly, bisinuate posteriorly, with obtuse median lobe, width ca 1.5 times length, ca 1.4-1.5 times as wide as head. Lateral sides slightly rounded and moderately narrowed in anterior two-thirds toward head, subparallel in posterior one-third, shortly margined basally. Anterior angle rounded; posterior angle rectangular and obtuse. Disc slightly flattened medially, surface lustrous, densely and coarsely punctate; spaces between punctures smaller than puncture diameter. Scutellum width ca $1.5-1.9$ times length.

ELYTRA. Elongate, narrowed posteriorly, apex rounded, as wide as pronotal width at humeri, length ca 2.6 times width, surface lustrous. Disc covered with oval punctures, denser in lateral and basal part; interspaces narrower as long as or slightly wider than puncture diameter. 4-8 faint traces of striae in each elytron from dorsal view, stria I fused with II (Fig. 4F), gradually shortened outwards, elytral striae indistinct in some specimens. Prosternum before procoxae about as long as shortest diameter of procoxae. Prosternal process long, margined laterally, rounded and narrowed apically; length behind procoxae longer than width between procoxae. Width between procoxae ca 0.4 times transverse coxa diameter. Mesoventrite with shallow, oval mesoventral cavity, smooth. Abdominal ventrite $\mathrm{V}$ truncated apically, with terminal margin serrate and slightly concave, serrations at both sides larger than in middle, lateral sides nearly straight (Fig. 4L); sternite VIII concave in middle of apical edge, forming two hornshaped lobes curved inwards on both sides, densely pubescent apically (Fig. 5L); sternite IX without spiculum gastrale on apical edge (Fig. 5R); tergite VIII without median strut on apical edge, subtruncated apically, emarginate in middle, densely pubescent apically (Fig. 5K); tergite IX and X completely fused, rounded apically, densely pubescent on apical edge (Fig. 5R).

Legs. Slender. Tarsomeres simple, tarsal formula 5-5-4. The longest spur of hind tibiae ca 0.2 times as long as first tarsal segment; length ratio of tarsomeres as follows: $2.50: 1.00: 0.50: 0.75$ (measured without claws). Claws serrate.

Aedeagus (Fig. 6O-P). Lanceloate, basal piece curved dorsally, lateral sides narrowed basically. Parameres narrowly separated apically, with inner margin narrowly concave, dorsal median part with a groove, lateral sides subparallel, slightly sinuate, strongly narrowed at apex, length ca 3.1-3.5 times maximum width. Median lobe elongate, clavate, slightly narrowed apically.

Female (Fig. 3K)

Measurements. Length: 8.00-9.25 mm; width: $2.00-2.25 \mathrm{~mm}$.

Body. Similar to males.

HEAD. Eyes smaller than in male, ratio of eye diameter to interocular space 1.0:1.6-1.9. Antennae shorter in male, when directed backwards extending the posterior edge of pronotum, antennomere XI ca 3.2 times as long as maximum width. Length ratio of antennomeres as follows: $2.00: 1.00: 2.30: 2.20: 2.05: 2.10: 2.05: 2.05: 2.10: 2.10: 2.90$.

Pronotum. Ca 1.5 times wider than length, ca 1.5 times as wide as head.

ELYTRA. Slightly wider than in male, as wide as pronotal width at humeri, length ca 2.5-2.6 times width.

OviPositor. Paraproct elongate, ca 2.6-2.8 times length of coxite, sides straight and subparallel; proctiger subtruncate. 


\section{Distribution}

Malaysia; Indonesia (West Sumatra, South Kalimantan), new record (see below) (Fig. 9).

\section{Notes}

This species was described based on specimens from "Perak, Sumatra" (Fairmaire 1898); however, Nikitsky (1999) mentioned that only "Perak" was written on the label, and there is no locality in Sumatra called Perak; it is in Malaysia. During our study S. tenuipennis is newly recorded for Indonesia, based on two specimens from West Sumatra and South Kalimantan, respectively.

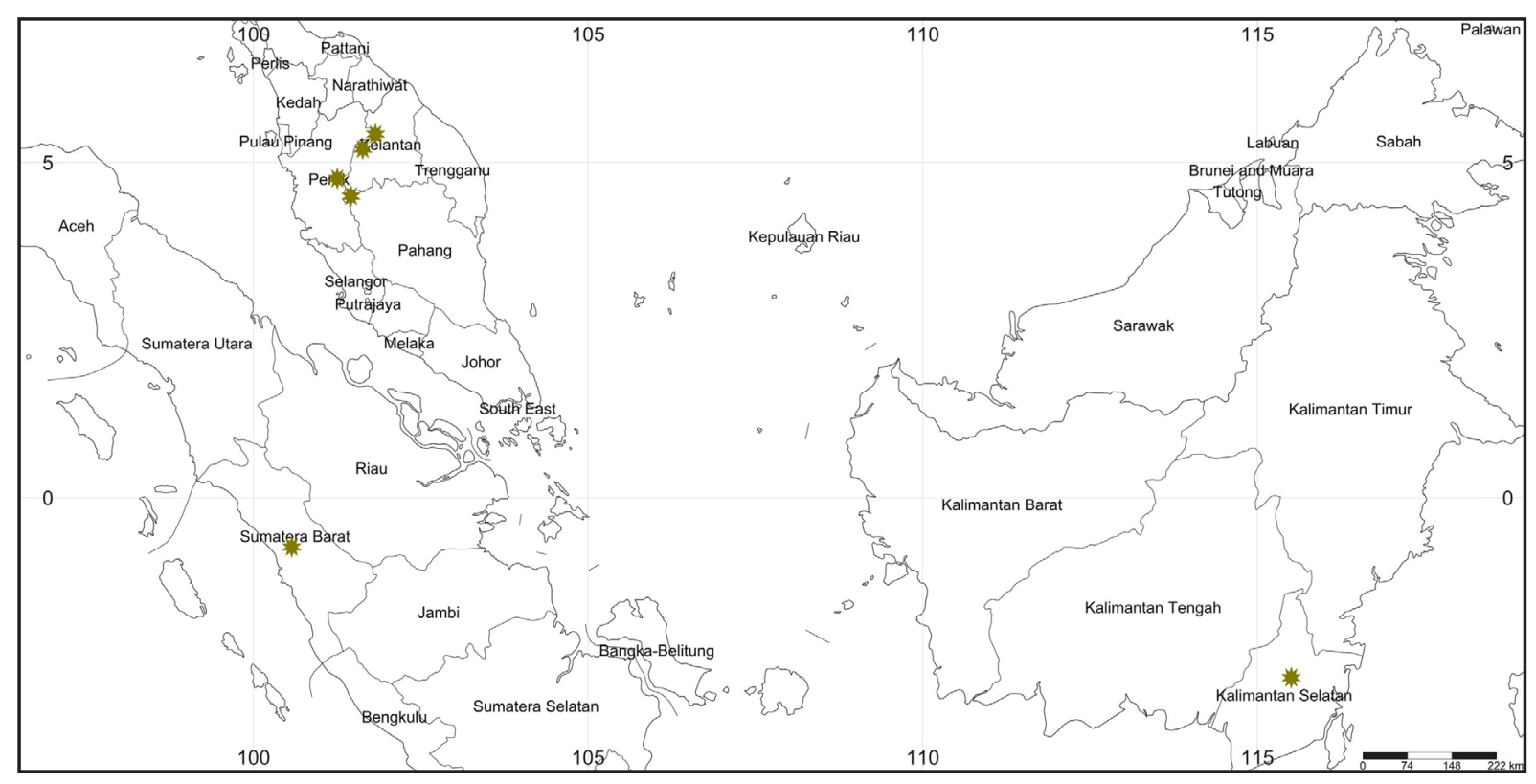

Fig. 9. Distribution map of Synchroina tenuipennis Fairmaire, 1898 from Malaysia and Indonesia.

Genus Thescelosynchroa gen. nov.

urn:1sid:zoobank.org:act:88962476-A4E1-4040-95E5-E2E4E314CDB0

\section{Type species}

Synchroa pangu Hsiao, Li, Liu \& Pang, 2016, here designated.

\section{Diagnosis}

This genus is similar to Synchroa and Synchroina; the differential diagnosis is given in Table 2.

\section{Etymology}

The genus name is composed of the Greek prefix 'Thescelos', meaning 'marvellous, wonderful' and the root-synchroa derived from the type genus of Synchroidae. It is feminine in gender. 


\section{Description}

\section{Male}

BoDy. Elongate, slender, slightly flattened, elytra rather strongly narrowed posteriorly.

HEAD. Eyes lateral, large, emarginate in front of antennal insertions. Antennae filiform, when directed backwards exceeding the humeri of elytra. Scape cylindrical, wider than other antennomeres, pedicel short, antennomere III-XI somewhat clavate, XI longest. Apical maxillary palpomere securiform, apical margin moderately rounded, terminal angle somewhat obtuse.

PRONOTUM. Truncate anteriorly, bisinuate posteriorly, with obtuse median lobe. Lateral sides rounded and narrowed in anterior two-thirds toward head, subparallel in posterior one-third. Anterior angle rounded; posterior angle rectangular and obtuse.

ELYTRA. Elongate, narrowed posteriorly, wider than pronotum at humeri (e.g., 1.2 times in holotype of type species). Prosternal process complete, broad, extending well beyond procoxae. Mesoventrite with shallow, oval mesoventral cavity, punctate.

LEGS. Slender. Tarsomeres simple, tarsal formula 5-5-4. Claws simple.

Aedeagus. Lanceloate. Parameres fused together forming apicale, narrowly separated apically and with a groove in dorsal median part. Median lobe long, slender and clavate, extending from the tegmen in natural condition.

\section{Female}

Unknown.

Thescelosynchroa pangu (Hsiao, Li, Liu \& Pang, 2016) gen. et comb. nov.

Figs $3 \mathrm{~L}, 6 \mathrm{Q}-\mathrm{R}$

Synchroa pangu Hsiao, Li, Liu \& Pang, 2016: 596.

\section{Material examined}

Holotype (Fig. 3L)

CHINA (mainland): đ, Sichuan prov., Ya'an, Tianquan, Labahe, 1500-2500 m, 8-9 Jul. 2012, Living [= Yun Li, Sun Yat-Sen University, Guangzhou, China] and M.-C. Chen leg. (SYSBM).

\section{Description}

See details in Hsiao et al. (2016).

\section{Notes}

Two errata were present in the original description and are corrected as follows: (1) the ventral view of aedeagus was misplaced as dorsal view in figures 6-8; (2) transverse coxal diameter is 4.38 times width between fore coxae, rather than the width between fore coxae 4.38 times transverse coxa diameter.

\section{Distribution}

China (Sichuan). 


\section{Discussion}

The division of Synchroidae into four major clades was mostly consistent with the current generic classification except Synchroa pangu (Fig. 10), which can be easily distinguished from other synchroids as summarized by Hsiao et al. (2016). Although this morphologically distinctive species was attributed to Synchroa, based on a previously established generic classification, the shape of the median lobe of the aedeagus of $S$. pangu suggests its relation with Synchroina. Apart from its unique characteristics, which make a possible placement in Synchroa or Synchroina difficult, the monophyly of this species as a distinct lineage is supported in our cladistic analysis. Therefore, we herein separate this species to propose a new genus.

Monophyly of Synchroidae has not been rigorously tested in this analysis, but based on previous research (Lawrence \& Newton 1995; Nikitsky 1999; Lawrence et al. 1999; Young 2002; Ślipiński \& Lawrence 2010), this group is mostly treated as a distinct family. Our phylogenetic analysis supports the monophyletic Synchroidae excluding Mallodrya subaenea. Mallodrya subaenea was originally placed in Melandryidae (Horn 1888) and shares several characters with some stenotrachelid and melandryid species, such as very short or absent interfacetal setae; a margined posterior pronotal edge; the prosternal process extending before posterior edges of coxae; the slightly projecting procoxae; the mesoventral cavity absent; the mesocoxae partly confluent; the mesometaventral junction absent. It implies that this species may be more related to these two families. The systematic placement of $M$. subaenea is possibly inappropriate and should be re-evaluated. Nevertheless, we herein chose not to exclude it from Synchroidae without a further examination of the adult genital organs, and larval characters and a comprehensive phylogenetic study of Tenebrionoidea.

The historical biogeography and speciation of synchroa bark beetles remain unclear. On the one hand, the Eastern Asian-North American disjunction (EA-NA disjunction) is present in the distribution pattern of the nominal genus. Given the greater species diversity, it implies that the area from Eastern Asia to northern Indochina could be the centre of origin of this group, especially Northwest China (Shaanxi, Gansu) to Southwest China (Sichuan) as well as northern Vietnam and Laos. This suggests the species

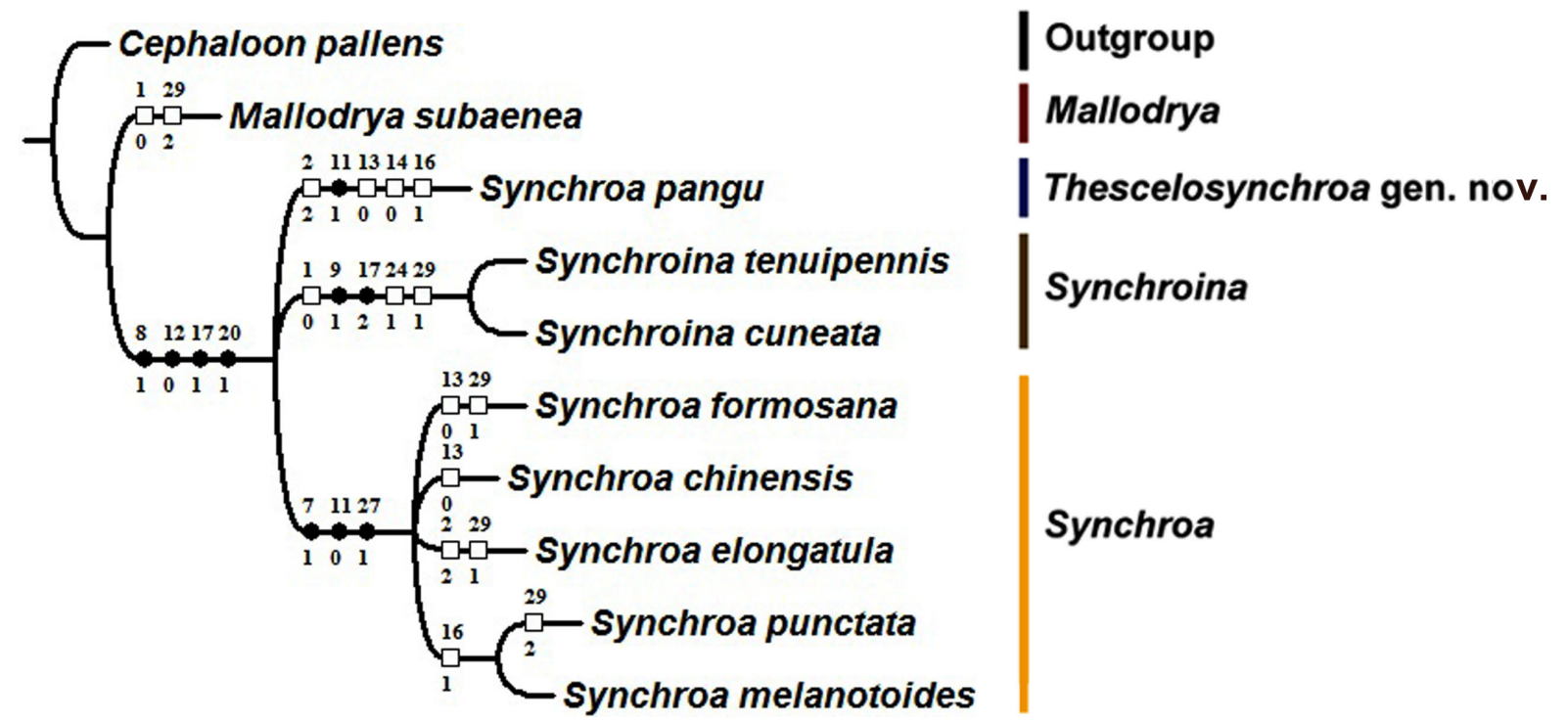

Fig. 10. Phylogenetic reconstruction of Synchroidae. Majority consensus tree with characters mapped on branches using unambiguous character changes in WinClada. Tree length $=54$; Consistency Index $=$ 81; Retention Index $=61$. 
diversification in Asia and dispersal of a branch to America is comparable in some cases of butterflies (Mullen 2006; Vila et al. 2011). The previous studies on the EA-NA disjunction primarily utilized plants as model organisms and the timing of most disjunctions could be dated to less than $30 \mathrm{Ma}$ (MidLate Tertiary), which suggests vicariance over the Bering Land Bridge (Wen 1999; Sanmartin et al. 2001; Donoghue \& Smith 2004; Ren et al. 2013). The studies of insects distributed in EA and NA, such as swallowtail butterflies of the Papilio elwesi species-group, support a dispersal route of the ancestor to Eurasia via the Bering Land Bridge (BLB) (Wu et al. 2015), and the cases of aphids and leaf beetles reveal a consistent biogeographic pattern with their host plants, highlighting the significance of host distribution for diversification (von Dohlen et al. 2002; Sota et al. 2008; Ren et al. 2013). Apart from its diversification in Eastern Asia, no species have been recorded in the western Palaearctic region. Given the wood-feeding on cambium of decaying deciduous trees during the immature stage (Payne 1931; Young 1991; Majka \& Pollock 2006) and the fossil record from the Late Eocene Florissant Formation of Colorado (34.07 $\pm 0.10 \mathrm{Ma}$, Evanoff et al. 2001), which corresponds to closure of the BLB, it is likely that the EANA disjunction of Synchroa could also be related to plant migration through BLB during Tertiairy climate change, although synchroids are not specialized phytophagous insects such as aphids and the classification of the Eocene $S$. quiescens Wickham, 1911 may require reevaluation.

On the other hand, the endemic genus Synchroina of West Malesia (i.e., the area west of Wallace's line), possibly originated from the route through the Indo-Chinese peninsula, as is the case for most plants and animals distributed in this area (Turner et al. 2001).

However, due to a lack of recognized synapomorphies in the phylogenetic analysis, the relationships among the members of this family are not well resolved, which results in difficulties proposing a biogeographic scenario to explain their distribution pattern and evolution. A molecular approach could solve the problem of insufficient characters to give a higher resolution to the relationships and date the timing of Synchroa disjunction. Further studies of phylogeny and historical biogeography are badly needed and will give insight into the evolutionary history of Synchroidae.

\section{Acknowledgments}

We wish to express our sincere thanks to Prof. Michael Ivie (MSU), Dr. Ming-Luen Jeng (NMNS), Dr. Jing-Fu Tsai (NMNS), Dr. Chi-Feng Lee (TARI) and Dr. Sheng-Shan Lu (TFRI) for their assistance in loaning specimens. Our thanks also go to Prof. Daniel K. Young (University of Wisconsin, Madison), Prof. Darren Pollock (Eastern New Mexico University, USA), Prof. Masahiro Ôhara (HUM), Mr. Kikuchi Namiki, Mr. Shu Makita (Hokkaido University, Japan), Prof. Hong Pang, Mr. Yun Li (Sun YatSen University, China), Mr. Masahiro Saitô (Sakai-shi, Japan), Prof. Ryoji Toyoshima (Nagoya, Japan), Dr. Enrico Ruzzier (Natural History Museum, London, and Venice, Italy), Mr. Radim Gabriš (Zlaté Hory, Czech Republic) and Dr. Eduard Jendek (Bratislava, Slovakia) for diverse assistance and providing material. Besides, we are indebted to the editor and anonymous reviewers for their suggestions for improving the manuscript.

\section{References}

Böving A.G. \& Craighead F.C. 1931. An illustrated synopsis of the principal larval forms of the order Coleoptera. Entomologica Americana 11: 1-351. https://doi.org/10.5962/bhl.title.6818

Champion G.C. 1916. Notes on Melandryidae. The Entomologist's Monthly Magazine 52: 1-157.

Crowson R.A. 1966. Observations on the constitution and subfamilies of the family Melandryidae (Coleoptera). Eos 41: 507-513. 
Donoghue M.J. \& Smith S.A. 2004. Patterns in the assembly of temperate forests around the Northern Hemisphere. Philosophical Transactions of the Royal Society B, Biological Sciences 359 (1450): 1633-1644. https://doi.org/10.1098/rstb.2004.1538

Evanoff E., McIntosh W.C. \& Murphy P.C. 2001. Stratigraphic summary and 40Ar/39Ar geochronology of the Florissant Formation, Colorado. Proceedings of the Denver Museum of Nature and Science, Series 4 1: 1-16.

Fairmaire L. 1898. Descriptions de coléoptères d'Asie et de Malaise. Annales de la Société entomologique de France 67: 382-400.

Goloboff P. 1999. NONA (NO NAME), ver. 2.0. Published by the author, Tucumán, Argentina.

Hayashi N. 1975. On the larvae of Melandryidae (Coleoptera, Cucujoidea) and some related families occurring in Japan. Kontŷu 43: 147-169.

Horn G. 1888. Miscellaneous coleopterous studies. Transactions of the American Entomological Society 15: 26-48. https://doi.org/10.2307/25076501

Hsiao Y. 2015. A new species of the genus Synchroa from Taiwan, with a key to the world fauna (Coleoptera: Synchroidae). Acta Entomologica Musei Nationalis Pragae 55 (1): 243-248.

Hsiao Y., Li Y., Liu Z. \& Pang H. 2016. A new species of Synchroa Newman from China (Coleoptera: Synchroidae). Zootaxa 4093 (4): 595-600. https://doi.org/10.11646/zootaxa.4093.4.13

Lawrence J.F. \& Newton A.F. Jr. 1995. Families and subfamilies of Coleoptera (with selected genera, notes and references, and data on family-group names). In: Pakaluk J. \& Ślipiński S.A. (eds) Biology, Phylogeny, and Classification of Coleoptera: Papers Celebrating the $80^{\text {th }}$ Birthday of Roy A. Crowson: 779-1006. Muzeum i Instytut Zoologii PAN, Warsaw.

Lawrence J.F., Hastings A.M., Dallwitz M.J., Paine T.A. \& Zurcher E.J. 1999. Beetles of the World: A Key and Information System for Families and Subfamilies. CD-ROM, Version 1.0 for MS-Windows. CSIRO Publishing, Melbourne.

Lewis G. 1895. XXXIV. - On the Cistelidæ and other Heteromerous species of Japan. Annals and Magazine of Natural History 15 (87): 250-278. https://doi.org/10.1080/00222939508677881

Löbl I. 2008. Family Synchroidae Lacordaire, 1859. In: Löbl I. \& Smetana A. (eds) Catalogue of Palaearctic Coleoptera, Vol. 5: 353. Apollo Books, Stenstrup, Denmark.

Majka C.G. \& Pollock D.A. 2006. Understanding saproxylic beetles: new records of Tetratomidae, Melandryidae, Synchroidae, and Scraptiidae from the Maritime Provinces of Canada (Coleoptera: Tenebrionoidea). Zootaxa 1248: 45-68.

McKenna D.D., Wild A.L., Kanda K., Bellamy C.L., Beutel R.G., Caterino M.S., Farnum C.W., Hawks D.C., Ivie M.A., Jameson M.L., Leschen R.A.B., Marvaldi A.E., Mchugh J.V., Newton A.F., Robertson J.A., Thayer M.K., Whiting M.F., Lawrence J.F., Ślipiński A., Maddison D.R. \& Farrell B.D. 2015. The beetle tree of life reveals that Coleoptera survived end-Permian mass extinction to diversify during the Cretaceous terrestrial revolution. Systematic Entomology 40: 835-880. https://doi.org/10.1111/syen.12132

Mullen S.P. 2006. Wing pattern evolution and the origins of mimicry among North American admiral butterflies (Nymphalidae: Limenitis). Molecular Phylogenetics and Evolution 39 (3): 747-758. https://doi.org/10.1016/j.ympev.2006.01.021

Newman E. 1838. Entomological notes. The Entomological Magazine 5: 372-402.

Nikitsky N.B. 1999. To the knowledge of beetles of the family Synchroidae (Coleoptera, Tenebrionoidea) in the world fauna. Entomological Review 79: 475-481. 
Nixon K.C. 2002. Winclada ver. 10.00.08. Published by the author, Ithaca, NY.

Payne N.M. 1931. Food requirements for the pupation of two coleopterous larvae, Synchroa punctata Newm. and Dendroides canadensis LeC. (Melandryidae, Pyrochroidae). Entomological News 42: 13-15.

Ren Z., Zhong Y., Kurosu U., Aoki S., Ma E., von Dohlen C.D. \& Wen J. 2013. Historical biogeography of Eastern Asian-Eastern North American disjunct Melaphidina aphids (Hemiptera: Aphididae: Eriosomatinae) on Rhus hosts (Anacardiaceae). Molecular Phylogenetics and Evolution 69 (3): 11461158. https://doi.org/10.1016/j.ympev.2013.08.003

Sanmartin I., Enghoff H. \& Rongquist F. 2001. Patterns of animal dispersal, vicariance and diversification in the Holarctic. Biological Journal of the Linnean Society 73 (4): 345-390. https://doi.org/10.1006/bij1.2001.0542

Shorthouse D.P. 2010. SimpleMappr, an online tool to produce publication-quality point maps. Available from http://www.simplemappr.net [accessed 28 Jan. 2018].

Ślipiński A. \& Lawrence J.F. 2010. 11.16. Synchroidae Lacordaire, 1859. In: Beutel R.G. \& Leschen R.A.B. (eds) Handbuch der Zoologie / Handbook of Zoology. Insecta: Coleoptera, Beetles, Vol. 2: 667-669. W. de Gruyter, Berlin.

Sota T., Bocak L. \& Hayashi M. 2008. Molecular phylogeny and historical biogeography of the Holarctic wetland leaf beetle of the genus Plateumaris. Molecular Phylogenetics and Evolution 46 (1): 183-192. https://doi.org/10.1016/j.ympev.2007.10.016

Turner H., Hovenkamp P. \& Van Welzen P.C. 2001. Biogeography of Southeast Asia and the West Pacific. Journal of Biogeography 28: 217-230. https://doi.org/10.1046/j.1365-2699.2001.00526.x

Vila R., Bell C.D., Macniven R., Goldman-Huertas B., Ree R.H., Marshall C.R., Bálint Z., Johnson K., Benyamini D. \& Pierce N.E. 2011. Phylogeny and palaeoecology of Polyommatus blue butterflies show Beringia was a climate-regulated gateway to the New World. Proceedings of the Royal Society B, Biological Sciences 278 (1719): 2737-2744. https://doi.org/10.1098/rspb.2010.2213

von Dohlen C.D., Kurosu U. \& Aoki S. 2002. Phylogenetics and evolution of the eastern Asianeastern North American disjunct aphid tribe, Hormaphidini (Hemiptera: Aphididae). Molecular Phylogenetics and Evolution 23 (2): 257-267.

https://doi.org/10.1016/S1055-7903(02)00025-8

Wen J. 1999. Evolution of Eastern Asian and Eastern North American disjunct distributions in flowering plants. Annual Review of Ecology and Systematics 30: 421-455.

https://doi.org/10.1146/annurev.ecolsys.30.1.421

Wickham H.F. 1911. Fossil Coleoptera from Florissant, with descriptions of several new species. Bulletin of the American Museum of Natural History 30: 53-69.

Wu L.-W., Yen S.-H., Lees D.C., Lu C.-C., Yang P.-S. \& Hsu Y.-F. 2015. Phylogeny and historical biogeography of Asian Pterourus butterflies (Lepidoptera: Papilionidae): A case of intercontinental dispersal from North America to East Asia. PLoS ONE 10 (10): e0140933. https://doi.org/10.1371/journal.pone.0140933

Young D.K. 1991. Synchroidae. In: Stehr F.W. (ed.) Immature Insects, Vol. II: 516-518. Kendall Hunt Publishing Company, Dubuque, Iowa.

Young D.K. 2002. 108. Synchroidae Horn 1888. In: Arnett R.H. Jr., Thomas M.C., Skelley P.E. \& Frank J.H. (eds) American Beetles. Volume 2. Polyphaga: Scarabaeoidea through Curculionoidea: 512-513. CRC Press, Gainesville, Florida. 
Manuscript received: 7 February 2017

Manuscript accepted: 19 June 2017

Published on: 23 February 2018

Topic editor: Gavin Broad

Section editor: Max Barclay

Desk editor: Kristiaan Hoedemakers

Printed versions of all papers are also deposited in the libraries of the institutes that are members of the EJT consortium: Muséum national d'Histoire naturelle, Paris, France; Botanic Garden Meise, Belgium; Royal Museum for Central Africa, Tervuren, Belgium; Natural History Museum, London, United Kingdom; Royal Belgian Institute of Natural Sciences, Brussels, Belgium; Natural History Museum of Denmark, Copenhagen, Denmark; Naturalis Biodiversity Center, Leiden, the Netherlands; Museo Nacional de Ciencias Naturales-CSIC, Madrid, Spain; Real Jardín Botánico de Madrid CSIC, Spain. 